\title{
Study on Vacuum Roasting Pretreatment of Carbonaceous Gold Concentrates Based on Nonoxidation Technology
}

\author{
Xinwei Zhang $\mathbb{D},{ }^{1,2}$ Yonghui Song $\mathbb{D}^{1},{ }^{1}$ Ning Yin $\mathbb{D}^{1},{ }^{1}$ Xinzhe Lan, ${ }^{1}$ and Jianping Jin ${ }^{3}$ \\ ${ }^{1}$ School of Metallurgical Engineering, Xi'an University of Architecture and Technology, \\ Key Laboratory of Gold and Resources of Shaanxi Province, Xi'an, Shaanxi 710055, China \\ ${ }^{2}$ Shaanxi Institute of International Trade \& Commerce, Xi'an, Shaanxi 712046, China \\ ${ }^{3}$ College of Resource and Civil Engineering, Northeastern University, Shenyang 110819, China \\ Correspondence should be addressed to Yonghui Song; syh1231@126.com
}

Received 24 June 2021; Revised 29 September 2021; Accepted 4 October 2021; Published 15 November 2021

Academic Editor: Gang Feng

Copyright (c) 2021 Xinwei Zhang et al. This is an open access article distributed under the Creative Commons Attribution License, which permits unrestricted use, distribution, and reproduction in any medium, provided the original work is properly cited.

\begin{abstract}
Carbonaceous gold ores are difficult to treat because of the "preg-robbing" by carbonaceous matters and locking by minerals. Roasting is the most commonly used method that is useful in dealing with carbonaceous gold ores. In this study, flotation gold concentrates containing sulfides and carbonaceous matters were investigated to ascertain the reaction process and the matters' transformation characteristics in different temperatures by vacuum roasting pretreatment. Calcine and volatile condensates were characterized with several techniques. In the process of vacuum roasting, the main chemical reactions were decomposition reaction and carbothermic reduction reactions of sulfide ores, carbothermic reduction reactions of $\mathrm{SiO}_{2}$, and thermal decomposition reactions of organic carbon. The bad effects of "preg-robbing" by carbonaceous matters were greatly weakened by the thermal decomposition and carbothermal reduction. The gold locking minerals were mainly removed by reduction reactions. The sulfides were removed in ways that did not produce $\mathrm{SO}_{2}$. The removal of sulfur and carbonaceous matters during the vacuum roasting process was $95.83 \%$ and $65.38 \%$, respectively. Direct cyanidation of the calcine extracted from $2.13 \%$ to $88.37 \%$ of the gold content with a vacuum degree of $10 \mathrm{~Pa}$ and roasting from $25^{\circ} \mathrm{C}$ to $1,200^{\circ} \mathrm{C}$ for $30 \mathrm{~min}$.
\end{abstract}

\section{Introduction}

With the depletion of oxide ores throughout the world, refractory gold ores are becoming of increasing importance to the mining industry [1]. Carbonaceous gold ores are important refractory gold ores in the world. In China, the accumulated resources of carbonaceous gold ores are 1,000 $t$, accounting for $8 \%$ of the gold resources and ranking second in the world [2-4]. Therefore, the development and utilization of carbonaceous gold ores have gained considerable attention [5].

In carbonaceous gold ores, the following conditions are observed: (i) Natural gold is usually locked by minerals, such as sulfide (e.g., gold is occasionally embedded in the crystal center of pyrite with fine grain size [6]), silicate, and carbonate $[1,7]$. It is difficult to expose gold for contacting with a leaching solution through fine grinding alone. (ii) Some simple and organic carbons in carbonaceous gold ores can easily absorb dissolved gold during cyanide leaching, which is called "preg-robbing" and seriously affects leaching. (iii) Part of the organic carbon itself can lock gold, which makes the gold recovery more difficult [8]. These factors make carbonaceous gold ores difficult to deal with. A small number of carbonaceous matters could have a significant impact on gold recovery. Riina Ahtiainen and others have found that the gold loss rate increased with the increase of carbonaceous matters' content in the carbonaceous gold ores. The gold loss rate was $29 \%$ when the carbonaceous matters' content was $0.01 \%$, but when the carbon content was more than $10 \%$, the gold was almost completely lost [9]. Therefore, the key problem in improving the gold leaching rate is to solve the influence of carbonaceous matters. In order to eliminate or passivate the carbonaceous matters, the carbonaceous gold ores can be pretreated before 
cyanidation, by methods such as blanking, roasting, chlorination, or biooxidation [10]. Roasting is the oldest and still the most commonly used pretreatment method, which is applied to heat the sulfides or arsenide ores in the air to remove sulfur, arsenic, carbonaceous matters, or other volatiles through the processes of combustion $[11,12]$. In the earlier study, the flotation experiments were conducted as the pretreatment method to delete the effect of carbonaceous matters, while the leaching effects were terrible. Then the conventional roasting experiments were conducted and the gold leaching rate had obviously improved but still did not reach the best. Considering the double refractory characteristic, the high carbon content of the sample, and the limitations on waste gas treatment, the focus of the later study was turned to the improvement of conventional roasting pretreatment technology [10].

Vacuum metallurgy technology has a good effect on improving metal recovery rate and shortening process flow in the field of minerals and metallurgy. The vacuum environment can meet the requirements of environmental protection, matters in the reaction system can be divided from the atmosphere, and the exchange of materials can be effectively controlled [13-15]. In the field of gold processing, vacuum technology is mainly used for the removal of arsenic and sulfur from arsenic-containing and sulfur-containing gold ores. The study found that, compared with the air and nitrogen atmosphere, the arsenic removal time in the vacuum was shorter, the temperature for arsenic removal was lower, and the arsenic removal rate was close to $98.97 \%$ at $1053.15 \mathrm{~K}$ and $3 \mathrm{~h}$ in the vacuum condition [16]. Many theoretical, technological, and equipment researches about vacuum technology have been carried out on the removal of arsenic from arsenic-bearing gold ore by vacuum method at the Technical University of Kazakhstan [17]. However, no relevant application of vacuum technology in the removal of carbon from carbonaceous gold ores has been found.

Carbothermal reduction technology is widely used in chemical and metallurgical industry, such as metal smelting, metal material preparation, lead-zinc oxide ore treatment, and other industrial productions. In recent years, the carbothermal reduction method has been applied to gold processing [18]. For example, based on the fluidized roasting coupling technology, the roasting process of reducing pyrolusite with carbonaceous gold ores was investigated. Corecovery of manganese from pyrolusite and gold from carbonaceous gold ores was achieved by this process. The results indicated that the optimum leaching efficiency of $99.31 \%$ for manganese and $97.43 \%$ for gold could be attained under the conditions that the mass ratio of carbonaceous gold ores to pyrolusite was $2: 3$, the coroasting temperature was $1073.15 \mathrm{~K}$, and the roasting time was $30 \mathrm{~min}$ [19]. The experimental result showed that the carbonaceous matters in the carbonaceous gold ores can be utilized under proper conditions. Recently, studies found that carbothermal reduction can achieve good results under the vacuum condition. Yucheng Liu [20] investigated the mechanism of carbothermal reduction of indium ore under the vacuum condition. The study found that the lower the system pressure was, the lower the initial reaction temperature of thermal decomposition of $\operatorname{In}_{2} \mathrm{O}_{3}$ to $\operatorname{In}_{2} \mathrm{O}$ and In would be. The Gibbs free energy in the reaction of $\mathrm{InO}$ and $\mathrm{CO}$ increases, and some side effects were difficult to occur. Luo Qi [21] have studied the vacuum carbothermal reduction characteristics of nickel laterite. The research showed that the vacuum system could improve the reduction efficiency of minerals at $973 \mathrm{~K}$ by changing the microstructure of most minerals, such as talc and nickel-bearing, and promote the thermal decomposition of the minerals.

In this study, the combination of vacuum metallurgy and carbothermal reduction technology was developed and used on the pretreatment of carbonaceous gold concentrates to synchronously solve the problem of minerals locking of gold and "preg-robbing" of carbonaceous and develop an environmentally friendly pretreatment process. The technology of vacuum roasting pretreatment has now obtained a Chinese national invention patent [22]. In this paper, the reactions process and the matters transformation characteristics in different temperature under the vacuum roasting pretreatment were studied in the present study. The variation characteristics of the calcine minerals compositions at different temperature stages and the volatile condensates were also analyzed to judge the reaction process. The study led to a deeper understanding of the technology and made up for the deficiencies in the theoretical study of this technology.

\section{Experimental}

2.1. Materials. A $5 \mathrm{~kg}$ carbonaceous gold concentrate samples for this study were obtained from a gold factory in the Qinling Mountains, Shaanxi Province. The raw carbonaceous gold ore in the factory was pulped to $35 \%$ solids and floated in Denver Flotation Cell. The pulp was conditioned with copper sulfate. Sodium isoamyl xanthate and terpenic oil were the collector and foaming agents. After three flotation procedures, carbonaceous gold concentrates were obtained. The particle size of carbonaceous gold concentrates was $70 \%$ passing size of $-75 \mu \mathrm{m}$.

The results of the process mineralogical analysis of the raw sample are shown in Figures 1 and 2 and Tables 1-3. Tables 1 and 2 show the chemical composition analysis and the mineral compositions of the raw sample. Figure 1 shows MLA images of the raw sample. Figure 2 shows the gold phase images of the raw sample. Table 3 presents the gold phase analysis results. Table 4 contains the carbon phase analysis results. The process mineralogical analysis results show that carbonaceous gold concentrate has a high quartz content of $72.34 \%$ and pyrite is the most abundant metal mineral at $6.50 \%$. The minerals are mainly irregularly granular and have no fixed alignment except that calcite is in a state of aggregation. The carbon content is high, with total carbonaceous material content being $14 \%$.

Gold phase analysis results show that gold exists in the form of natural gold with irregular shape and fine particle size less than $10 \mu \mathrm{m}$. The gold in Figure 2(a) is in the form of single gold. The phenomenon of gold being locked is serious. $65.35 \%$ of gold was locked by minerals, and the highest content of locking minerals was sulfides for $43.57 \%$. 


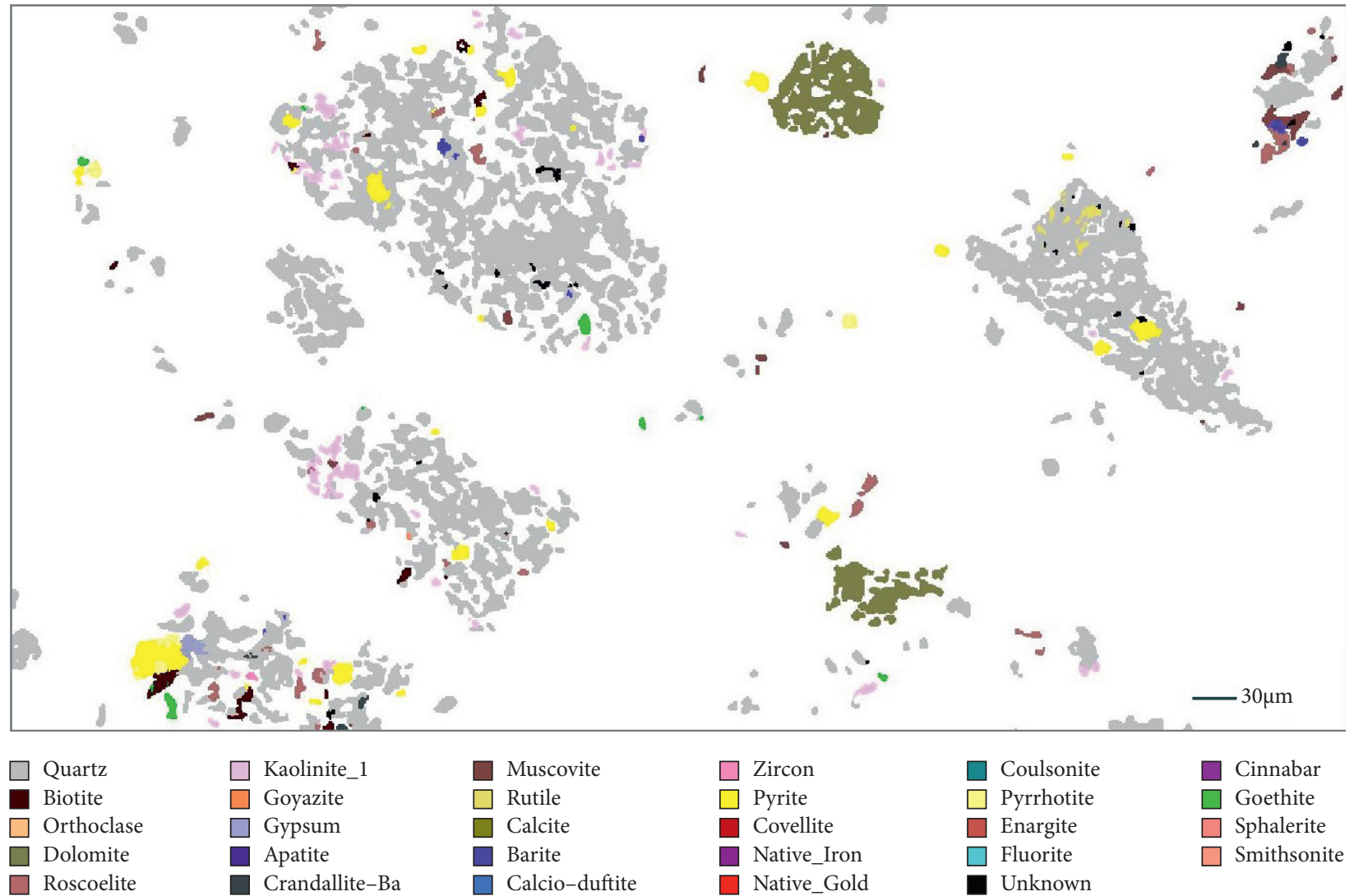

FIgURE 1: MLA images of the raw sample.

Figures 2(b) and 2(c) show locked gold and intergrowth gold. The gold in Figure 2(b) is locked by quartz, and the gold in Figure 2(c) is intergrown with pyrite.

2.2. Experimental Procedure. The flotation concentrates were washed several times with water and dried at $80^{\circ} \mathrm{C}$ in a drying oven; after that, samples were fully mixed. A $30 \mathrm{~g}$ of samples was put into a corundum porcelain boat and was placed in the center of the heating area of the quartz tube (Figure 3). Heat from $25^{\circ} \mathrm{C}$ to the aimed temperature under $10 \mathrm{~Pa}$ vacuum degree and keep the aimed temperature for $30 \mathrm{~min}$. The aimed temperatures were $600^{\circ} \mathrm{C}, 700^{\circ} \mathrm{C}, 800^{\circ} \mathrm{C}$, $900^{\circ} \mathrm{C}, 1,000^{\circ} \mathrm{C}, 1,100^{\circ} \mathrm{C}$, and $1,200^{\circ} \mathrm{C}$. Every sample was cooled down to room temperature in vacuum environment after roasting, after which the weight was taken. With the limited capacity of the quartz tube, several roasting experiments were conducted under the same conditions, and the calcine was mixed to analyze and conduct leaching experiments under each set of conditions.

Cyanidation tests were directly performed on $100 \mathrm{~g}$ after the vacuum roasting pretreatment processes. Leaching was performed at $35 \%$ solids by weight and the cyanide strength was maintained at $2 \mathrm{~kg} / \mathrm{t}$. The pulp was continuously stirred at a stirring speed of $300 \mathrm{r} / \mathrm{min}$. The $\mathrm{pH}$ was maintained between 11 and 13 using $\mathrm{CaO}$ powder. The leaching time was $12 \mathrm{~h}$. The gold content of cyanidation tailing was detected by the detection institution using Flame Atomic Absorption Method (TAS-900). In order to reduce the experimental error, the average gold leaching rate was obtained for 3 times using leaching tests.

2.3. Analysis and Characterization. The process mineralogical analysis of the raw samples was performed by an FEI Mineral Liberation analyzer Model 250, equipped with a scanning electron microscope (FEI QUANTA 650) and energy spectrometer (EDAX APOLLO X). X-ray photoelectron spectroscopy (XPS) measurement was carried out on a Thermo ESCALAB 250Xi device, using an $\mathrm{Al} \mathrm{K \alpha}$ monochromatic X-ray source operated at $150 \mathrm{~W}$ and $15 \mathrm{keV}$. The pressure inside the analysis chamber was maintained below $1 \times 10^{-8} \mathrm{mbar}$. The emission angle is $60^{\circ}$, and the size of the analyzed area is $500 \times 500 \mu \mathrm{m}$. The survey spectra were taken in the mode with analyzer pass energy $100 \mathrm{eV}$ and energy step $1 \mathrm{eV}$. Detailed spectra of characteristic XPS lines were taken in the mode with analyzer pass energy $30 \mathrm{eV}$ and energy step $0.01 \mathrm{eV}$. Energy shift was compensated by referencing all the spectra to a C1s signal taken as $284.8 \mathrm{eV}$ which comes from the adventitious carbon with an aliphatic nature (sp3) and a characteristic signal at $284.8-285.0 \mathrm{eV}$. With the difference of sample exhibits in different environments and exposure time, calibration with C1s may have errors [23]. To avoid the influence of the probable errors on the result of XPS analysis, the sample composition test results, a large number of references, and XPS standard spectrum library were referenced to ensure the accuracy of the XPS analysis results. The volatile condensates were 

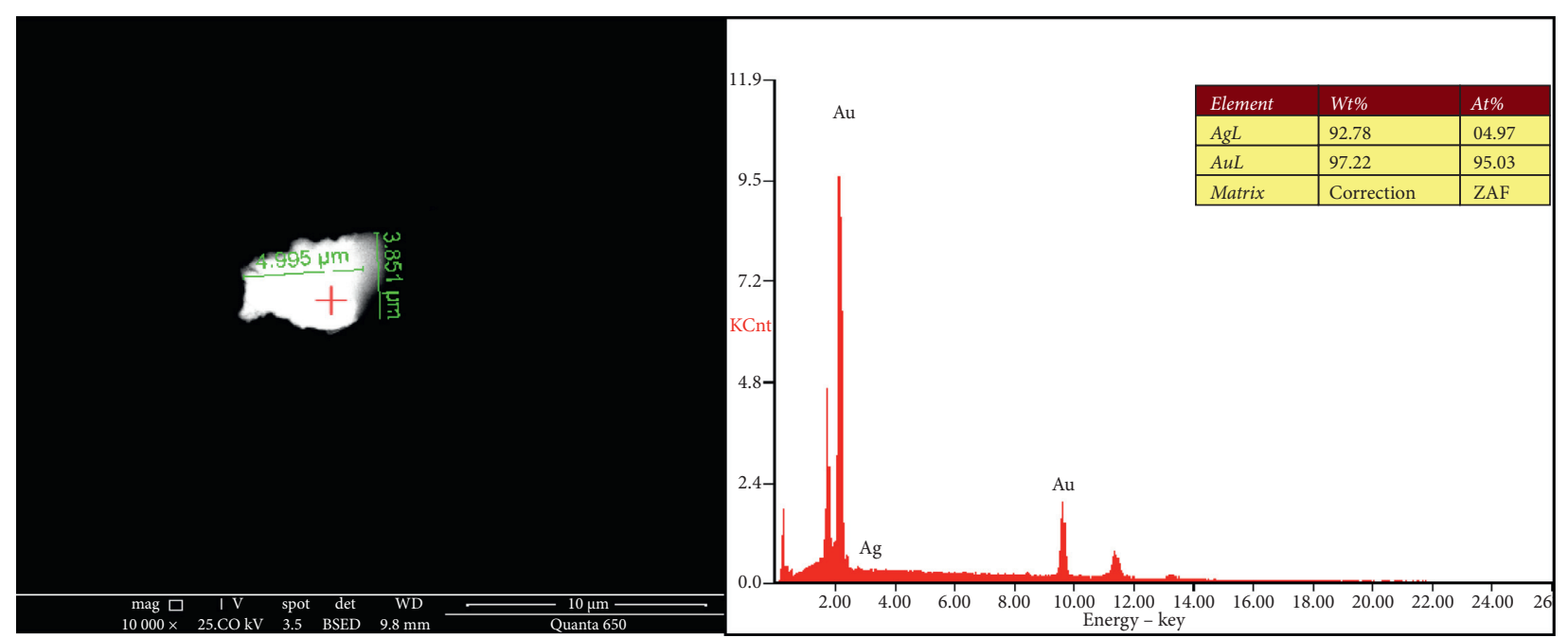

(a)
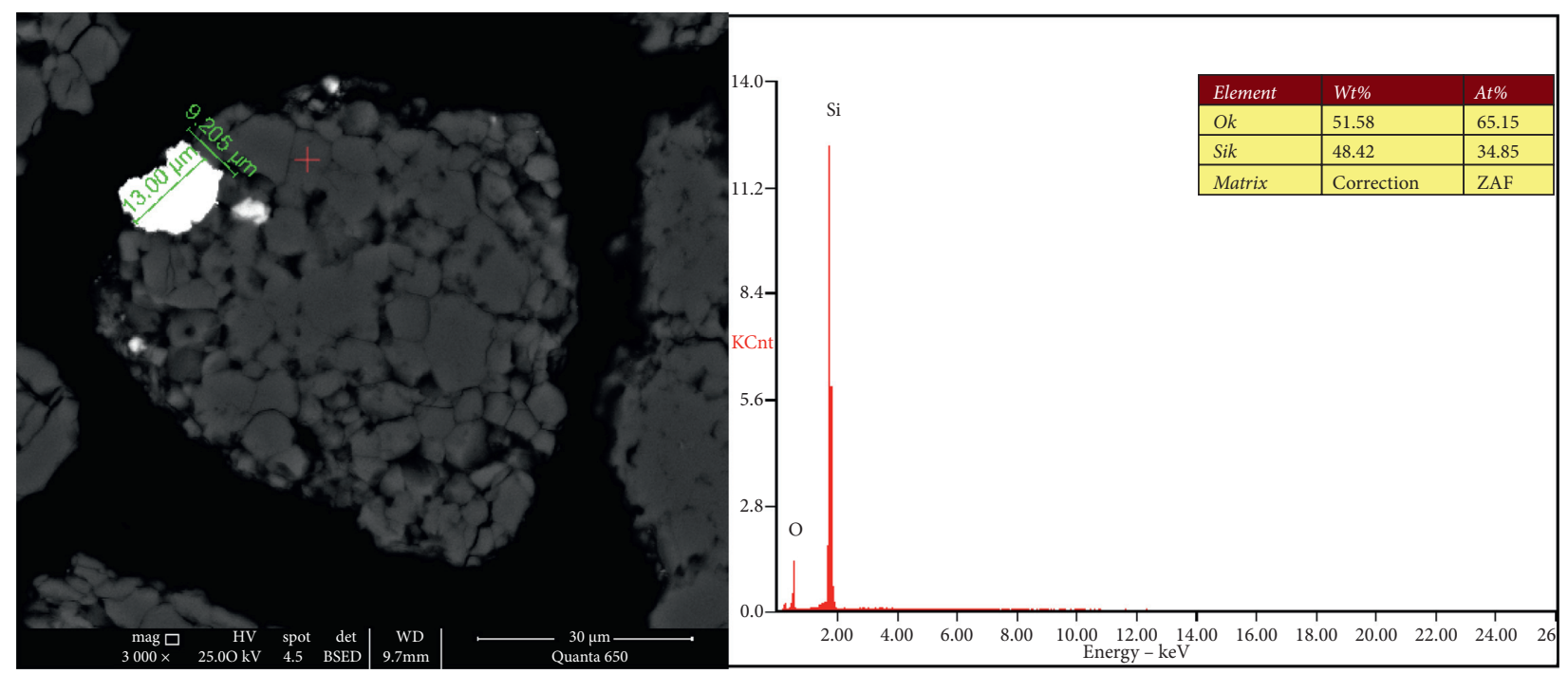

(b)
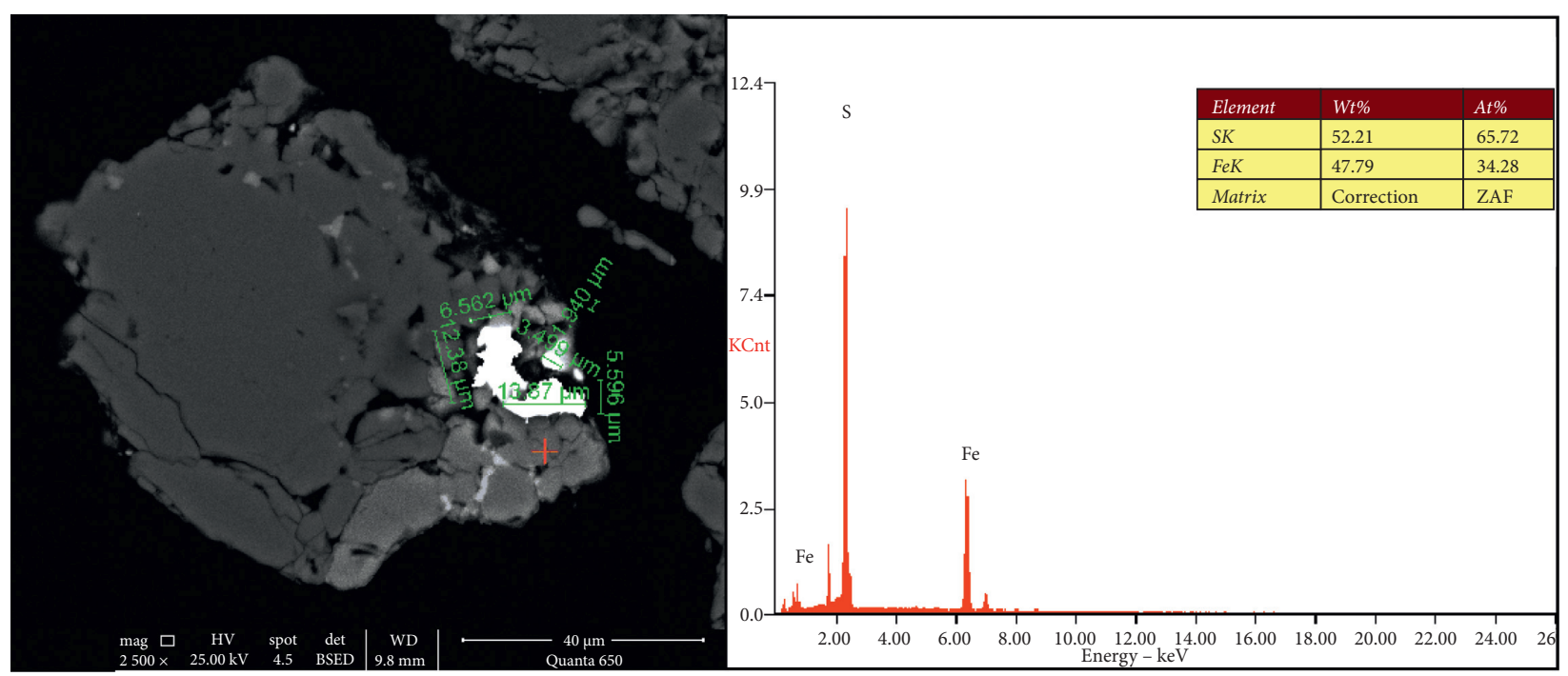

(c)

FIGURE 2: Gold phase images of the raw sample. (a) Native gold in a single form. (b) Native gold locked by quartz. (c) Native gold intergrown with pyrite. 
TABle 1: Chemical composition of the sample.

\begin{tabular}{lccccccccc}
\hline Element & $\mathrm{Mg}$ & $\mathrm{Al}$ & $\mathrm{Si}$ & $\mathrm{P}$ & $\mathrm{S}$ & $\mathrm{Cl}$ & $\mathrm{K}$ & $\mathrm{Ca}$ & $\mathrm{V}$ \\
\hline Wt\% & 1.78 & 2.64 & 31.78 & 0.35 & 4.72 & 0.02 & 0.6 & 1.78 & 0.54 \\
Element & $\mathrm{Ti}$ & $\mathrm{Cr}$ & $\mathrm{Mn}$ & $\mathrm{Fe}$ & $\mathrm{Ni}$ & $\mathrm{Cu}$ & $\mathrm{Zn}$ & $\mathrm{Sr}$ \\
Wt\% & 0.19 & 0.09 & 0.12 & 3.62 & 0.05 & 0.15 & 0.10 & 0.09 & 0.64 \\
Element & $\mathrm{Y}$ & $\mathrm{Zr}$ & $\mathrm{As}$ & $\mathrm{Hg}$ & $\mathrm{Sb}$ & $\mathrm{Se}$ & $\mathrm{Au}(\mathrm{g} / \mathrm{t})$ & \\
Wt\% & 0.01 & 0.01 & 0.05 & 0.01 & 0.02 & 0.01 & 15.52 & \\
\hline
\end{tabular}

TABLe 2: Mineral compositions of the sample.

\begin{tabular}{|c|c|c|c|c|c|}
\hline Mineral name & Molecular formula & Weight percent $(\mathrm{Wt} \%)$ & Area percent (area\%) & Particle counts & Mineral number \\
\hline Quartz & $\mathrm{SiO}_{2}$ & 72.34 & 76.85 & 109448 & 126686 \\
\hline Pyrite & $\mathrm{FeS}_{2}$ & 6.50 & 3.62 & 7874 & 9795 \\
\hline Goethite & $\mathrm{Fe}_{2} \mathrm{O}_{3} \cdot \mathrm{H}_{2} \mathrm{O}$ & 3.33 & 2.45 & 5415 & 7963 \\
\hline Roscoelite & $\mathrm{K}(\mathrm{V}, \mathrm{Al}, \mathrm{Mg})_{2} \mathrm{AlSi}_{3} \mathrm{O}_{10}(\mathrm{OH})_{2}$ & 3.33 & 3.23 & 7764 & 9080 \\
\hline Kaolinite & $\mathrm{Al}_{2} \mathrm{O}_{3} \cdot 2 \mathrm{SiO}_{2} \cdot 2 \mathrm{H}_{2} \mathrm{O}$ & 2.98 & 3.19 & 6827 & 8556 \\
\hline Muscovite & $\mathrm{KAl}_{2}\left[\mathrm{Si}_{3} \mathrm{AlO}_{10}\right](\mathrm{OH}, \mathrm{F})_{2}$ & 2.58 & 2.54 & 4348 & 4796 \\
\hline Barite & $\mathrm{BaSO}_{4}$ & 1.88 & 1.17 & 1348 & 2036 \\
\hline Dolomite & $\mathrm{CaMg}\left(\mathrm{CO}_{3}\right)_{2}$ & 1.74 & 1.70 & 1663 & 1866 \\
\hline Apatite & $\mathrm{Ca}_{5}\left(\mathrm{PO}_{4}\right)_{3}(\mathrm{~F}, \mathrm{Cl}, \mathrm{OH})$ & 1.45 & 1.27 & 1034 & 1183 \\
\hline Pyrrhotite & $\mathrm{Fe}_{\mathrm{x}} \mathrm{S}_{\mathrm{x}+1}$ & 0.85 & 0.51 & 1031 & 1159 \\
\hline Potash feldspar & $\mathrm{K}_{2} \mathrm{O} \cdot \mathrm{Al}_{2} \mathrm{O}_{3} \cdot 6 \mathrm{SiO}_{2}$ & 0.21 & 0.23 & 385 & 461 \\
\hline Sphalerite & $\mathrm{ZnS}$ & 0.14 & 0.10 & 86 & 87 \\
\hline Calcite & $\mathrm{CaCO}_{3}$ & 0.05 & 0.05 & 45 & 54 \\
\hline Native gold & $\mathrm{Au}$ & - & - & 1 & 1 \\
\hline Others & - & 2.62 & 3.09 & 8902 & 11566 \\
\hline
\end{tabular}

TABLe 3: Gold phase analysis of the sample.

\begin{tabular}{lcc}
\hline Phase classification & $\mathrm{W}(\mathrm{Au})\left(\mathrm{g} \cdot \mathrm{t}^{-1}\right)$ & Rate of distribution $(\%)$ \\
\hline Exposed and semiexposed gold & 5.17 & 34.65 \\
Carbonate-locked gold & 0.60 & 4.02 \\
Hematite and limonite-locked gold & 1.27 & 8.51 \\
Sulfides-locked gold & 6.50 & 43.57 \\
Silicate-locked gold & 1.38 & 9.25 \\
Total & 14.92 & 100.00 \\
\hline
\end{tabular}

TABLE 4: Chemical phase analysis of $\mathrm{C}$ and $\mathrm{S}$ contents at different conditions.

\begin{tabular}{lccccrcr}
\hline \multirow{2}{*}{ Treatment conditions $\left({ }^{\circ} \mathrm{C}\right)$} & \multirow{2}{*}{$\mathrm{S}(\%)$} & & \multicolumn{3}{c}{ Chemical phase of C (\%) } \\
& & & Graphite carbon & Carbonate & Organic carbon & Total \\
\hline \multirow{2}{*}{ Untreated } & \multirow{2}{*}{3.36} & Content & 0.68 & 0.35 & 12.97 & 14.00 \\
& & Distribution & 4.86 & 2.50 & 92.64 & 100.00 \\
\hline \multirow{2}{*}{800} & \multirow{2}{*}{2.53} & Content & 0.46 & 0.14 & 13.36 & 13.96 \\
& & Distribution & 3.30 & 1.00 & 95.70 & 100.00 \\
\hline \multirow{2}{*}{1,200} & \multirow{2}{*}{0.14} & Content & 1.88 & 0.74 & 7.49 & 7.11 \\
& & Distribution & 26.44 & 10.41 & 63.15 & 100.00 \\
\hline
\end{tabular}

characterized by X-ray diffraction (XRD) on an Xpert Pro MPD device and energy dispersive X-ray spectroscopy SEMEDS on a TESCAN Vega3 device.

\section{Results and Discussion}

3.1. Analysis of Sample Quality Changes. Table 4 shows the results of the $\mathrm{C}$ phase analysis and $\mathrm{S}$ contents of the samples in different conditions. The $\mathrm{S}$ content in gold concentrates continuously decreased with the increase of temperature. Finally, it decreased by $95.83 \%$ when the temperature increased to $1,200^{\circ} \mathrm{C}$ compared with the original sample. Some yellow gas gradually appeared in the quartz tube at $500^{\circ} \mathrm{C}-600^{\circ} \mathrm{C}$. The organic carbon content decreased by $8.48 \%$ compared with the original sample. The remaining $4.49 \%$ of organic carbon might be the reaction residue. The graphite content slightly decreased at $800^{\circ} \mathrm{C}$ because of the redox consumption [24], while it increased at $1,200^{\circ} \mathrm{C}$ 


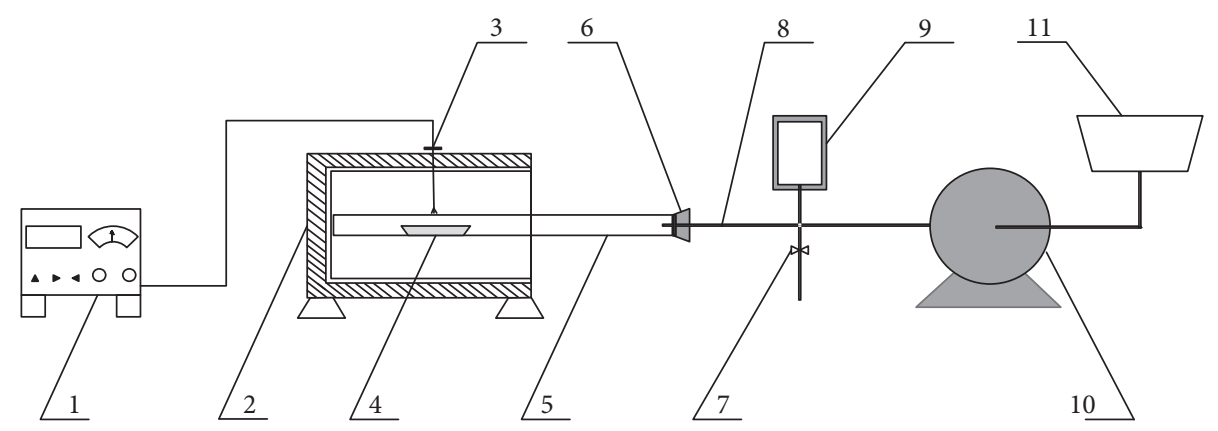

FIGURE 3: Schematic of the experimental setup; 1: furnace temperature controller; 2: vacuum tube furnace; 3: temperature sensor; 4: corundum boat; 5: quartz tube; 6: rubber plug; 7: valve; 8: airway; 9: Mai's vacuum gauge; 10: sliding vane rotary vacuum pump; 11: gas collector.

because of the fact that thermal decomposition of organic carbon could form graphite at a high temperature. The decomposition reaction reduced the carbonate content to $800^{\circ} \mathrm{C}$. As the temperature continues to rise, the carbonate content would be increased, and this might be related to the ash produced by the thermal decomposition of organic carbon.

Table 5 shows the results of sample quality variation at different temperatures. The mass loss of samples gradually increased with the increase of temperature, and the increase of mass loss changed obviously at $800^{\circ} \mathrm{C}$ and reached the maximum of $37.80 \%$ at $1,200^{\circ} \mathrm{C}$.

\subsection{The Process of Minerals Phase Transformation}

3.2.1. XPS Analysis of Calcine. Figure 4 shows the XPS analysis of the total spectrum of samples at different conditions. As shown in Figure 4, the characteristic peak of the elements in the sample had changed obviously after vacuum roasting. The evident change occurred at $1,200^{\circ} \mathrm{C}$ with the absorption peak strength of $\mathrm{Fe} 2 \mathrm{p}$ and $\mathrm{C} 1 \mathrm{~s}$ weakened, but Si $2 p$ enhanced. The binding energy of S $2 p$, Fe $2 p$, and Si $2 p$ was slightly offset compared with untreated samples when roasted at $800^{\circ} \mathrm{C}$ (Table 6), but it immensely changed at $1,200^{\circ} \mathrm{C}$ with $\mathrm{S} 2 \mathrm{p}$ and Fe $2 \mathrm{p}$, respectively, having only one binding energy peak at 173.54 and $710.04 \mathrm{eV}$ and $\mathrm{Si} 2 \mathrm{p}$ having a new binding energy peak at $101.24 \mathrm{eV}$. The results showed that the existing form of some elements like $\mathrm{S}, \mathrm{Fe}$, and $\mathrm{Si}$ was changed obviously at $1,200^{\circ} \mathrm{C}[25]$.

The narrow peak scanning analysis was conducted on the main elements under different conditions to make a clearer analysis of the reaction process. Figure 5 shows the narrow peak scanning analysis of $S 2 p, F e 2 p, S i 2 p$, and $O 1 s$.

It can be seen from Figure 5 and the mineral compositions of the sample (Table 2) that S 2p mainly existed in the form of metal sulfate and sulfide in the untreated samples. The corresponding peak value of $S 2 p$ gradually decreased with the increase of roasting temperature, and it nearly disappeared at $1,200^{\circ} \mathrm{C}$. The result shows that the $\mathrm{S}$ element was effectively reduced or removed in the reaction process, while whether there was any remaining S-containing substance needs further verification.
TABle 5: Sample quality variation at different roasting temperatures.

\begin{tabular}{lccc}
\hline $\begin{array}{l}\text { Treatment } \\
\text { temperature }\left({ }^{\circ} \mathrm{C}\right)\end{array}$ & $\begin{array}{c}\text { Mass before } \\
\text { treatment }(\mathrm{g})\end{array}$ & $\begin{array}{c}\text { Mass after } \\
\text { treatment }(\mathrm{g})\end{array}$ & $\begin{array}{c}\text { Mass } \\
\text { loss }(\%)\end{array}$ \\
\hline Untreated & 12 & - & - \\
600 & 11.77 & 11.04 & 6.26 \\
700 & 11.93 & 11.09 & 7.04 \\
800 & 11.95 & 11.04 & 7.65 \\
900 & 11.88 & 10.86 & 8.65 \\
1,000 & 11.86 & 10.72 & 9.61 \\
1,100 & 11.90 & 10.11 & 15.06 \\
1,200 & 11.88 & 7.39 & 37.80 \\
\hline
\end{tabular}

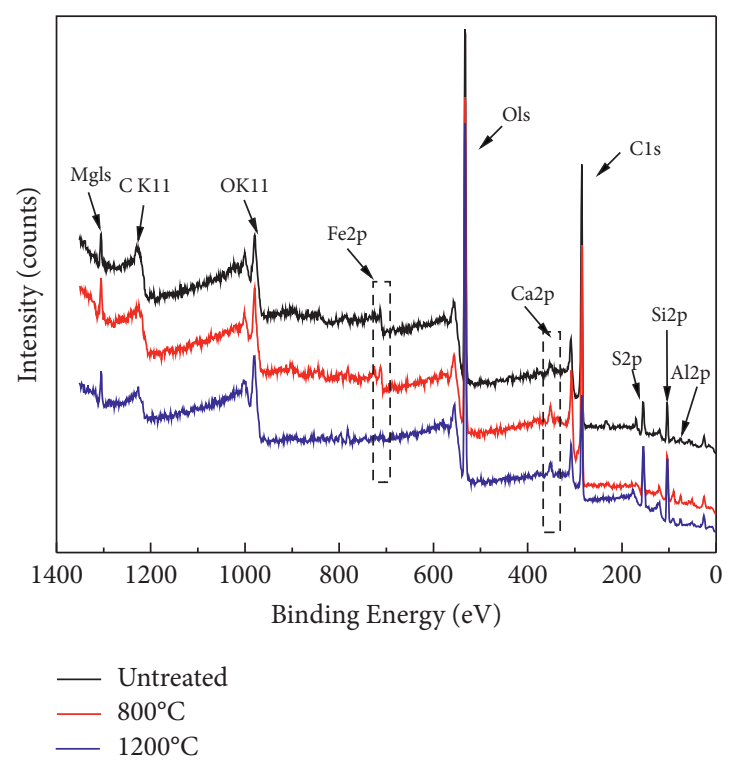

FIGURE 4: XPS analysis of the total spectrum of samples at different conditions.

In $\mathrm{Fe} 2 \mathrm{p}$ spectrum, the peak values of $711.70 \mathrm{eV}$ and $725.66 \mathrm{eV}$ corresponded to $\mathrm{Fe}-\mathrm{O}$ bond in the untreated samples [26], and the peak of binding energy in other positions was not obvious to judge the existence state of Fe. The peak of Fe $2 \mathrm{p}$ decreased gradually with the increase of roasting temperature, and it nearly disappeared at $1,200^{\circ} \mathrm{C}$. It can be seen that an obvious chemical reaction took place in 
TABLe 6: Binding energy of the inner-layer electrons of the main elements on the sample surface at different conditions.

\begin{tabular}{|c|c|c|c|c|c|}
\hline \multirow{2}{*}{ Treatment conditions } & \multicolumn{5}{|c|}{ Binding energy $(\mathrm{eV})$} \\
\hline & S 2p & Fe $2 p$ & Si $2 \mathrm{p}$ & C 1s & $\mathrm{O} 1 \mathrm{~s}$ \\
\hline \multirow{2}{*}{ Untreated } & 170.27 & 711.70 & 103.60 & 284.81 & 532.64 \\
\hline & 164.64 & 725.66 & & & \\
\hline \multirow{2}{*}{$800^{\circ} \mathrm{C}$} & 169.56 & 711.81 & 103.96 & 284.80 & 532.93 \\
\hline & 164.09 & 726.36 & & & \\
\hline $1,200^{\circ} \mathrm{C}$ & 173.54 & 710.04 & 103.71101 .24 & 284.80 & 532.75 \\
\hline
\end{tabular}

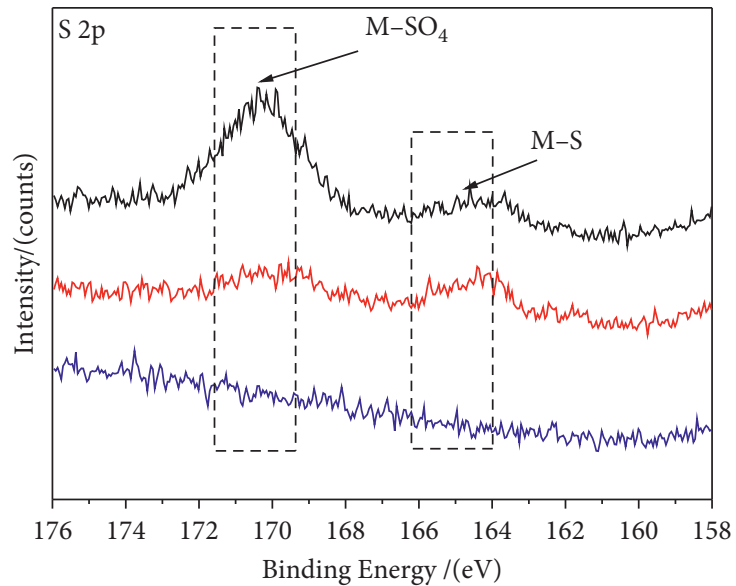

Untreated
$-800^{\circ} \mathrm{C}$

$-1200^{\circ} \mathrm{C}$

(a)

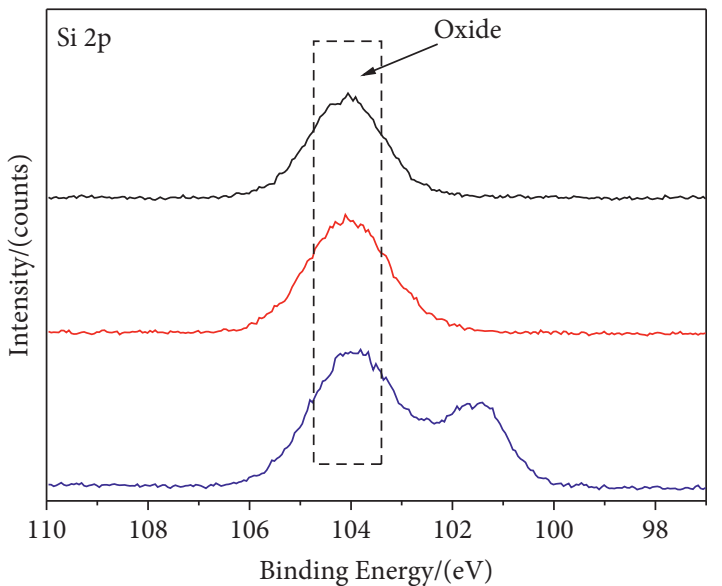

- Untreated
$-800^{\circ} \mathrm{C}$
$-\quad 1200^{\circ} \mathrm{C}$

(c)

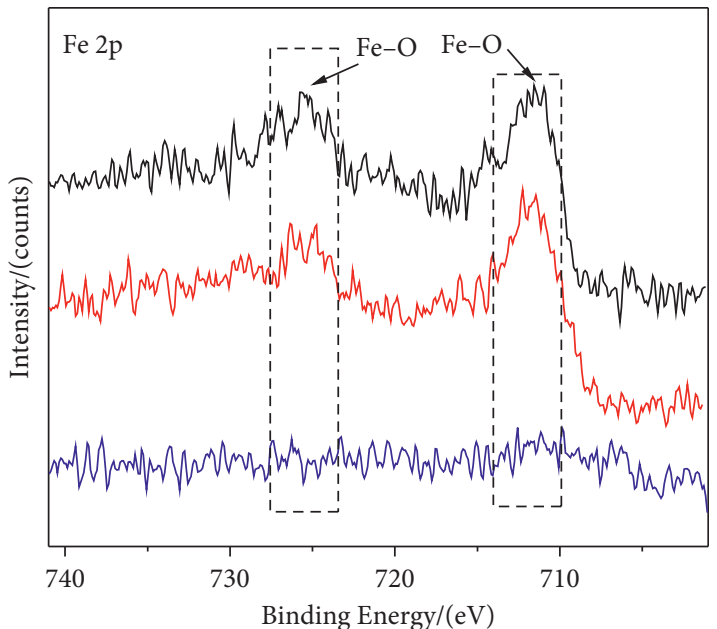

- Untreated

$-800^{\circ} \mathrm{C}$

$-1200^{\circ} \mathrm{C}$

(b)

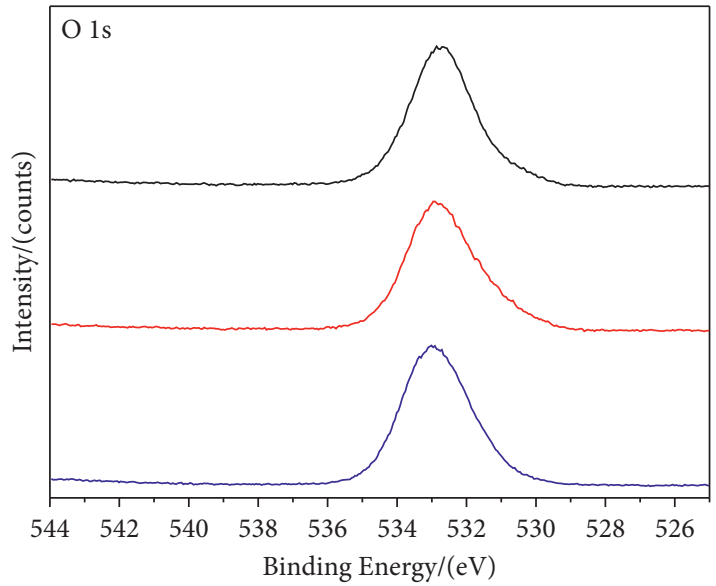

— Untreated

$-800^{\circ} \mathrm{C}$

$-1200^{\circ} \mathrm{C}$

Figure 5: Spectra of S 2p, Fe 2p, Si 2p, and O 1s at different conditions.

the $\mathrm{Fe}-\mathrm{O}$ bond substances in the roasting process, and $\mathrm{Fe}-\mathrm{O}$ bond substances nearly disappeared under the condition of treating them at $1,200^{\circ} \mathrm{C}$. The final results showed that this process can significantly solve the problem of gold being locked in goethite.
Si $2 \mathrm{p}$ spectrum seemed to be very similar under the untreated conditions and was treated at $800^{\circ} \mathrm{C}$ conditions, which showed that the existence morphology of $\mathrm{Si}$ had not changed obviously by vacuum roasting at $800^{\circ} \mathrm{C}$ [27]. At $1,200^{\circ} \mathrm{C}$, there was an obvious peak at the binding energy of 
$101.24 \mathrm{eV}$, which indicated that some reactions happened on Si-containing materials and the existence form might have changed. In order to observe the final reaction products of $\mathrm{Si}$, the spectra deconvolution of Si $2 p$ was conducted (Figure 6). Finally, combined with the mineral compositions of the sample (Table 2), $\mathrm{Si}$ had three existence states of $\mathrm{SiO}_{2}$, aluminosilicate, and $\mathrm{SiC}$ (the corresponding binding energy was $103.92 \mathrm{eV}, 101.93 \mathrm{eV}$, and $101.29 \mathrm{eV}) . \mathrm{SiO}_{2}$ and aluminosilicate were the substances in the original sample. $\mathrm{SiC}$ $[28,29]$ was a new product, which was probably due to a reaction between $\mathrm{C}$ and a siliceous material.

The spectra characteristics of $\mathrm{O}$ 1s looked similar at the three treatment conditions. With the main presence states of oxygen being stable forms, the corresponding substance states of oxygen had little change. The spectra deconvolution of $\mathrm{O} 1 \mathrm{~s}$ at $1,200^{\circ} \mathrm{C}$ was conducted (Figure 6) to analyze the final products. Two peaks at $532.93 \mathrm{eV}$ and $531.84 \mathrm{eV}$ corresponded to existence states of $\mathrm{O}\left(\mathrm{SiO}_{2}\right.$ and organic $\left.\mathrm{C}-\mathrm{O}\right)$ [27]. Other existence states of $\mathrm{O}$ were not found, possibly because the content was too low to be detected.

In order to study the change of carbonaceous matters in the reaction process, the spectra deconvolution of $\mathrm{C} 1 \mathrm{~s}$ was conducted (Figure 7). As it can be seen from Figure 7, the peaks of C 1s were at 283.99, 284.8, 285.54, 286.55, and $289.07 \mathrm{eV}$ in the untreated samples, but it changed at $800^{\circ} \mathrm{C}$ and disappeared at the peak at $289.07 \mathrm{eV}$, and the position of other peaks did not change much. At $1,200^{\circ} \mathrm{C}$, there were two new peaks appearing at $289.70 \mathrm{eV}$ and $283.41 \mathrm{eV}$. According to the results of the sample composition and the standard spectrum library of the electron binding energy of C, it can be inferred that the corresponding substances at $289.07 \mathrm{eV}$ and $289.70 \mathrm{eV}$ were metal carbonate [30, 31], the corresponding substances were $\mathrm{C}-\mathrm{O}$ bonds substances (organic carbon) at $285.54 \mathrm{eV}$ [32], the binding energy at $286.55 \mathrm{eV}$ corresponded to $\mathrm{C}=\mathrm{O}$ bonds substances (organic carbon), the binding energy at $283.99 \mathrm{eV}$ corresponded to $\mathrm{C}=\mathrm{C}$ carbon substances (graphite) [33], and the binding energy at $283.41 \mathrm{eV}$ might correspond to $\mathrm{SiC}$, which might be the product of new reaction like carbothermic reduction reaction in the process [32]. It was worth noting that carbonate in the samples was not detected at $800^{\circ} \mathrm{C}$, which indicates that the carbonates might have been decomposed, but it appeared at $1,200^{\circ} \mathrm{C}$, indicating that the reaction might produce new carbonate; this result was consistent with the previous phase analysis result of carbon.

3.2.2. SEM-EDS and XRD Analysis of Volatile Condensates. In the vacuum roasting process, volatile condensates were different at different temperatures. At $800^{\circ} \mathrm{C}$, a small amount of yellow condensate was found in the quartz tube, but it was too less to be detected. Therefore, the volatile condensate at $1,200^{\circ} \mathrm{C}$ was detected and analyzed. Figure 8 shows the photo of volatile condensates in the quartz tube wall at $1,200^{\circ} \mathrm{C}$. Figure 9 shows the results of SEM-EDS analysis of volatile condensates.

As shown in Figures 9(a)-9(g), evident differences could be found between the morphology of volatile condensates. The main elements of volatile condensates were $\mathrm{Si}, \mathrm{S}$, and $\mathrm{O}$, whereas $\mathrm{Na}, \mathrm{Mg}, \mathrm{P}, \mathrm{K}$, and $\mathrm{Zn}$ were few. A large amount of rod-like structure matter might correspond to $\mathrm{SiO}_{2}$ (Figure 9(a)). The matter in Figure 9(b) looked compact and it contained a large amount of $\mathrm{Si}$ and $\mathrm{S}$ and a small amount of $\mathrm{MgO}$ and $\mathrm{K}_{2} \mathrm{O}$. In Figure 9(c), the materials with heterogeneous spherical structure were mainly $\mathrm{SiS}_{2}$ and minimal $\mathrm{ZnO}$. In Figure 9(d), with the little content of other elements, the flake shape matter seemed to correspond to $\mathrm{Si}$. In Figure 9(e), ZnS was the main matter of the uniformly dispersed sphere. The matter in Figure 9(f) seemed to be similar to Figure 9(d), the morphology was cluster-like and rich, which might be Si. As shown in Figure 9(g), the interface of the product was flat, and the corresponding substances were $\mathrm{Si}$ and $\mathrm{ZnO}$.

Figure 10 presents the XRD analysis of the volatile condensates at $1,200^{\circ} \mathrm{C}$. The diagram showed that the volatile condensates were mainly composed of $\mathrm{S}, \mathrm{Si}, \mathrm{SiO}_{2}, \mathrm{SiS}_{2}, \mathrm{ZnO}$, $\mathrm{ZnS}$, and $\mathrm{MgO}$. Under the vacuum condition, the $\mathrm{S}$ in the volatile condensates came from the decomposition reaction of $\mathrm{FeS}_{2}$. The $\mathrm{Si}$ and $\mathrm{SiO}_{2}$ condensates might be the intermediate product of the carbothermal reduction reaction of $\mathrm{SiO}_{2}$ [33]. $\mathrm{MgO}$ might be produced by the decomposition reaction of dolomite. $\mathrm{SiS}_{2}$ condensed on the tube wall might be formed through the contact reaction of Si and sulfur gas [34]. The $\mathrm{ZnS}$ and $\mathrm{ZnO}$ condensates might be produced by the volatilization and other unknown reactions of $\mathrm{ZnS}$, respectively.

3.3. Analysis of Gold Dissociation Effect. Table 7 shows the gold phase analysis of calcine at $1,200^{\circ} \mathrm{C}$. Compared with the results of untreated samples in Table 3, the content of exposed and semiexposed gold increased from $34.65 \%$ to $57.56 \%$; this result showed that the gold liberation had been improved and gold leaching would be easier than the raw sample. The content of sulfides-locked gold had greatly reduced from $43.57 \%$ to $5.57 \%$, which showed that the vacuum roasting could effectively solve the gold locking problem by sulfides.

\subsection{The Main Reaction Process and Mechanism}

3.4.1. The Thermodynamic Analysis of Main Minerals. The main chemical reactions and the whole reaction process of vacuum roasting pretreatment of carbonaceous gold concentrate were obtained by combining the analysis results of calcine and volatile condensates. The main chemical reactions were decomposition reaction (equation (1)) and carbothermic reduction reactions (equations (2) and (3)) of pyrite [35], carbothermic reduction reactions of $\mathrm{SiO}_{2}$ (equations (4) and (5)) [36], and thermal decomposition reaction of organic carbon (equation (6)) [37, 38]. The results of thermodynamic analysis of the main chemical reactions in the vacuum roasting pretreatment processes are shown in Figure 11.

$$
\begin{aligned}
2 \mathrm{FeS}_{2} & =\mathrm{S}_{2}(\mathrm{~g})+2 \mathrm{FeS}, \\
2 \mathrm{FeS}_{2}+\mathrm{C} & =\mathrm{CS}_{2}(\mathrm{~g})+2 \mathrm{FeS},
\end{aligned}
$$




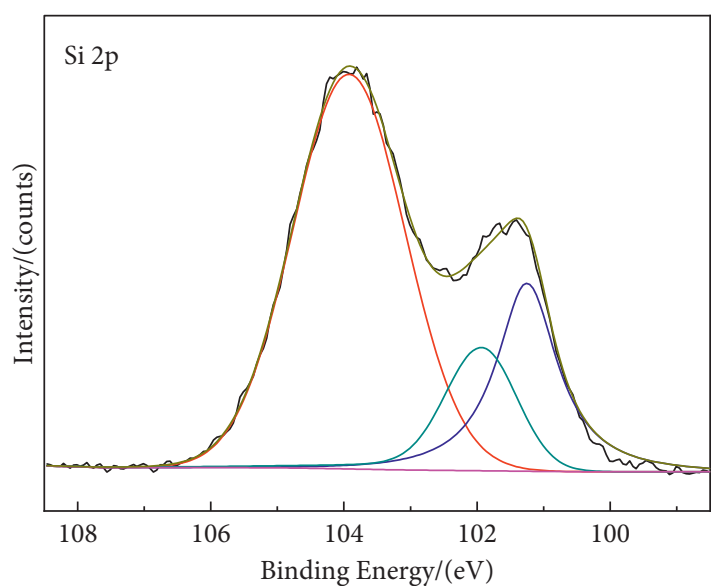

$\begin{array}{ll}- \text { experimental data } & - \text { Aluminosilicate } \\ \mathrm{SiO}_{2} & - \text { the best fit } \\ \mathrm{SiC} & \end{array}$

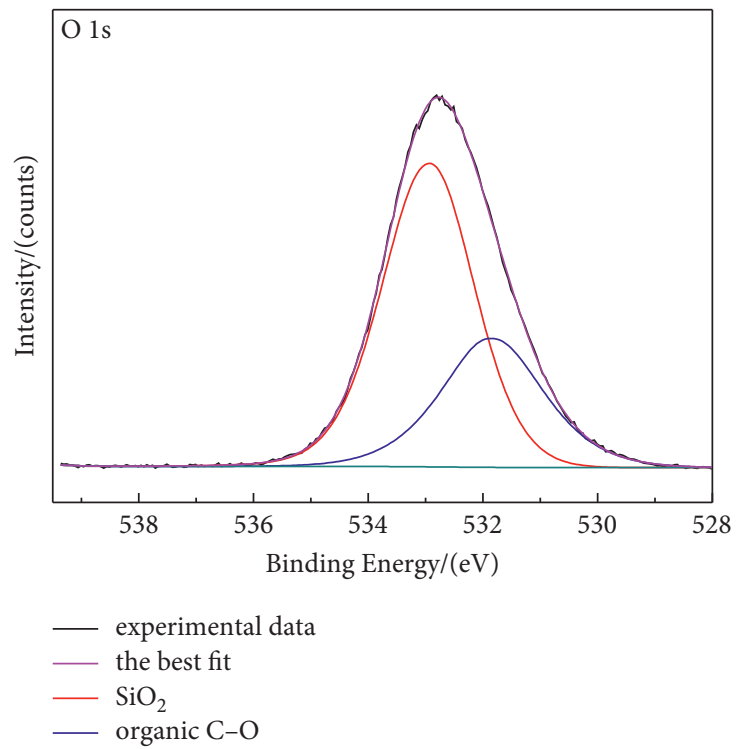

(b)

FIgURE 6: The spectra deconvolution of Si $2 \mathrm{p}$ and $\mathrm{O} 1 \mathrm{~s}$ at $1,200^{\circ} \mathrm{C}$.

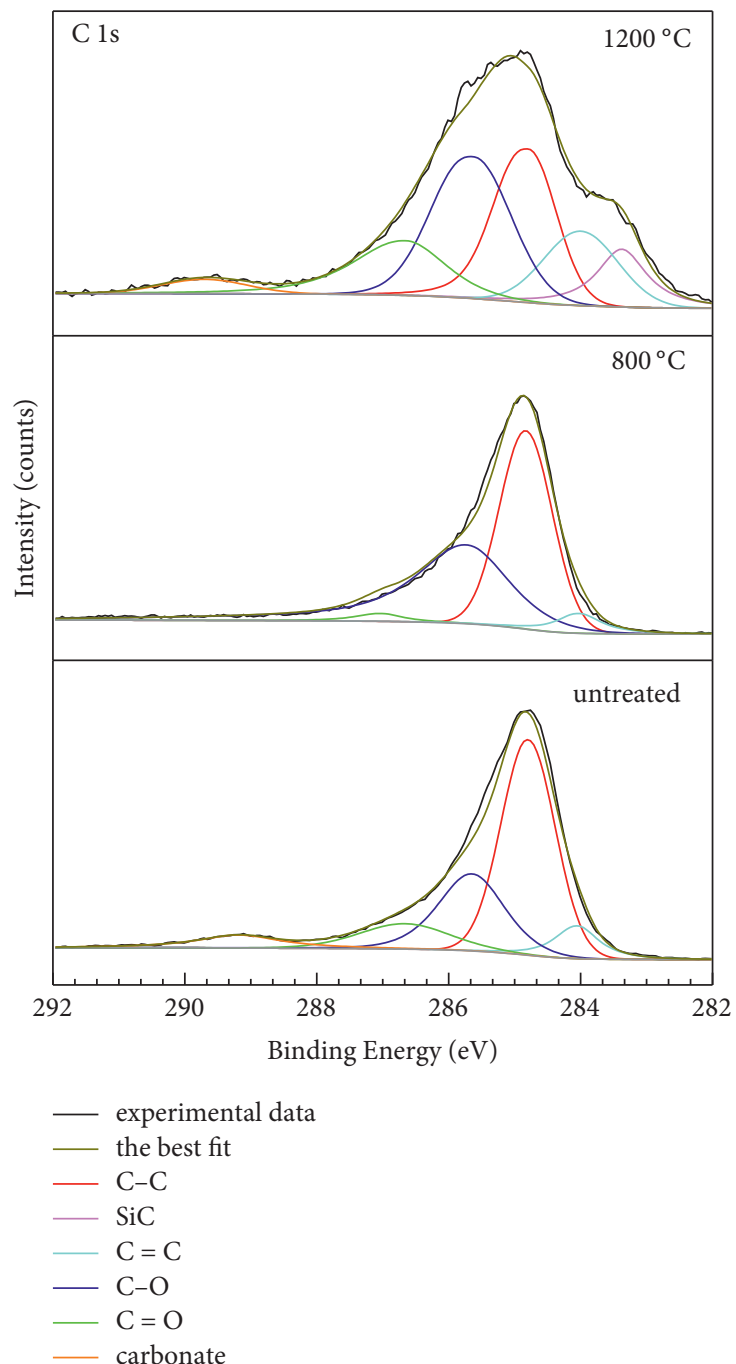

FIgURE 7: The spectra deconvolution of $\mathrm{C} 1 \mathrm{~s}$ at different conditions. 


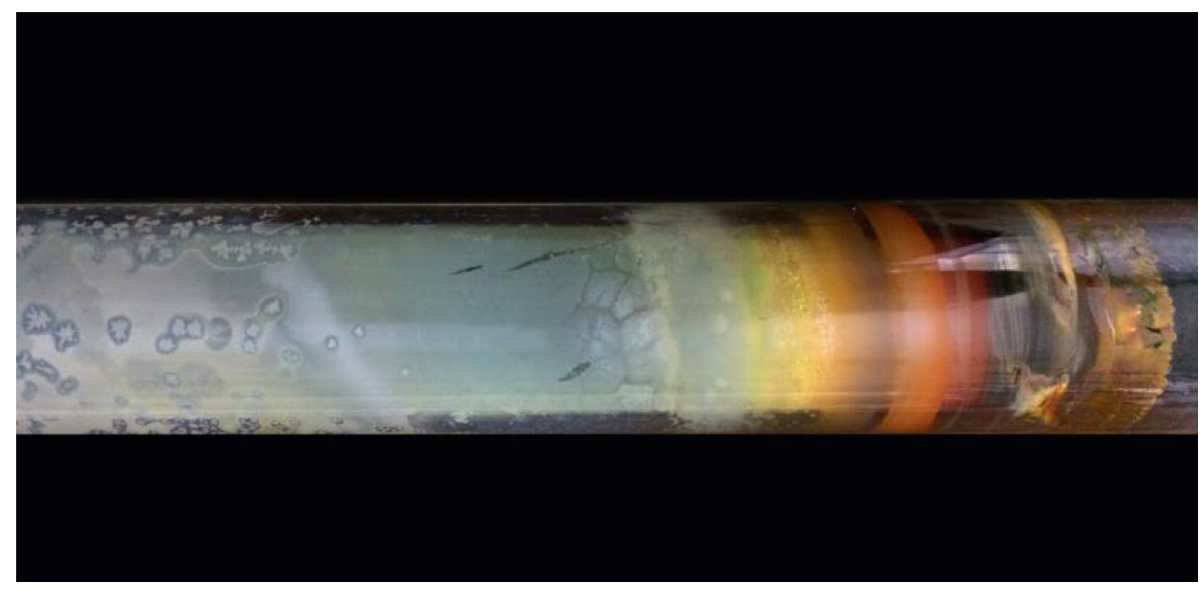

FIgUre 8: Photo of the volatile condensates at $1,200^{\circ} \mathrm{C}$.
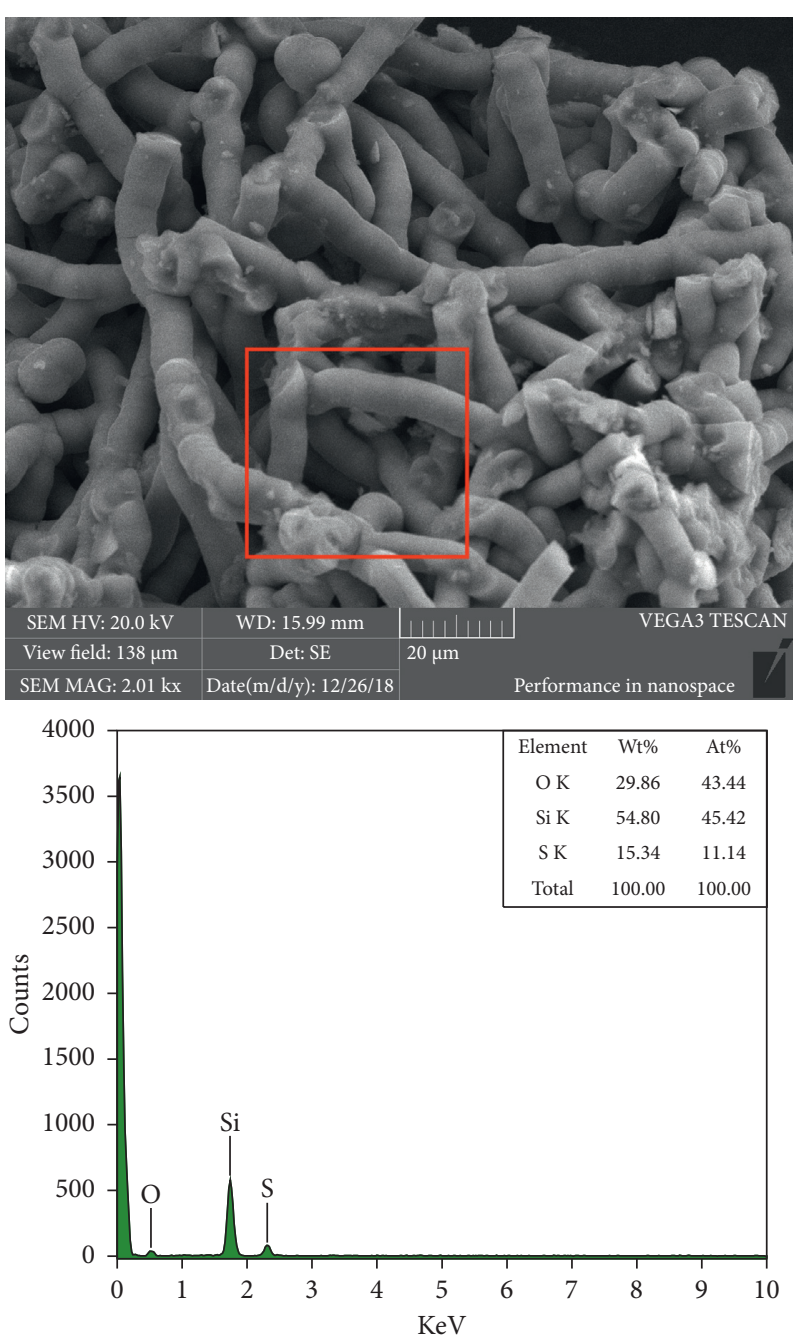

(a)
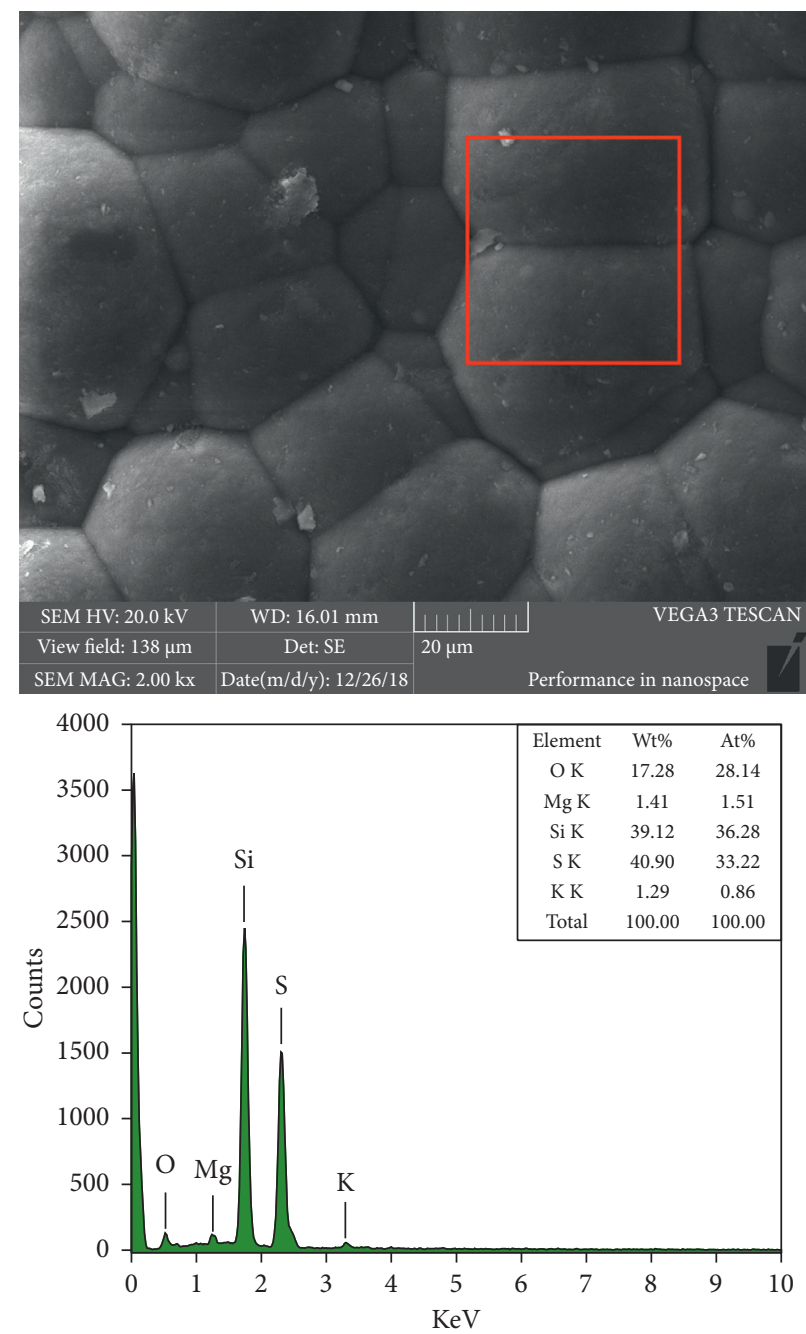

(b)

FIgURE 9: Continued. 

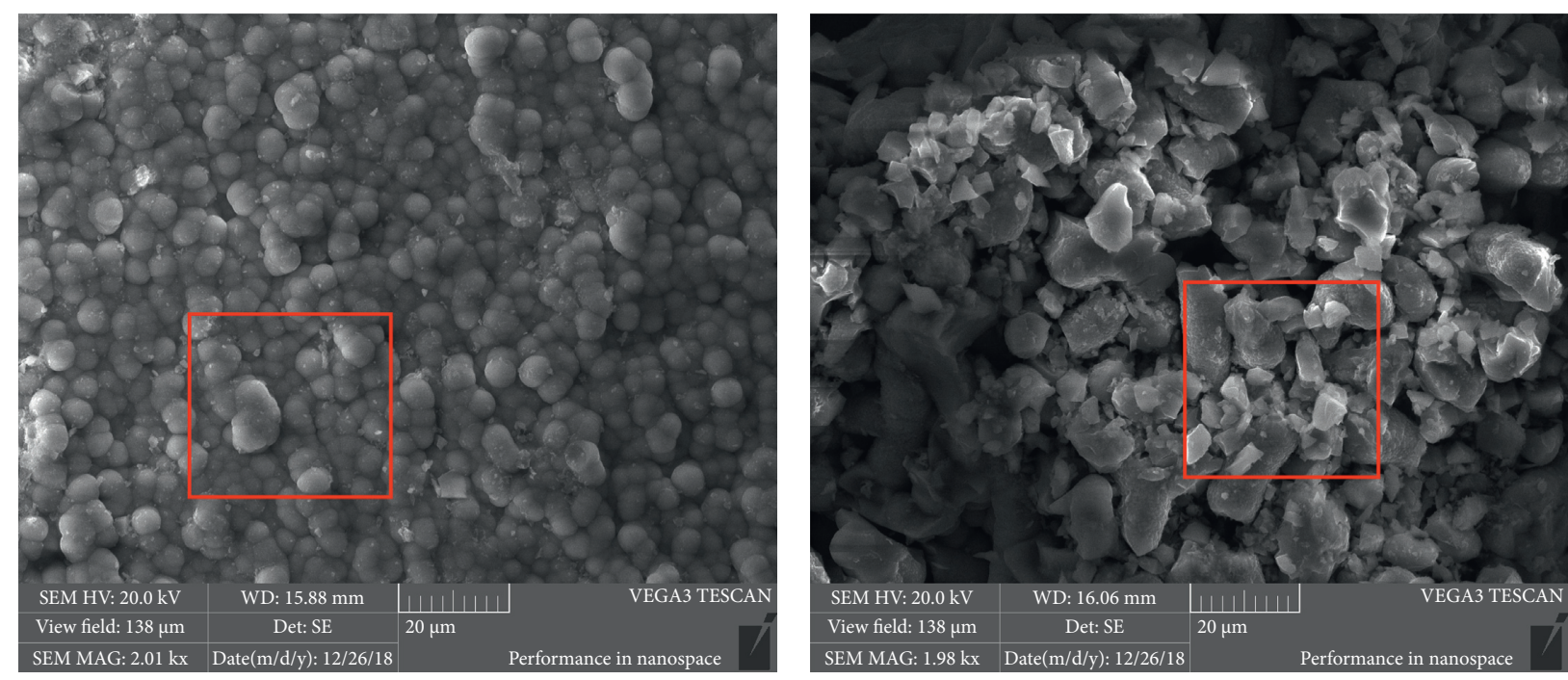

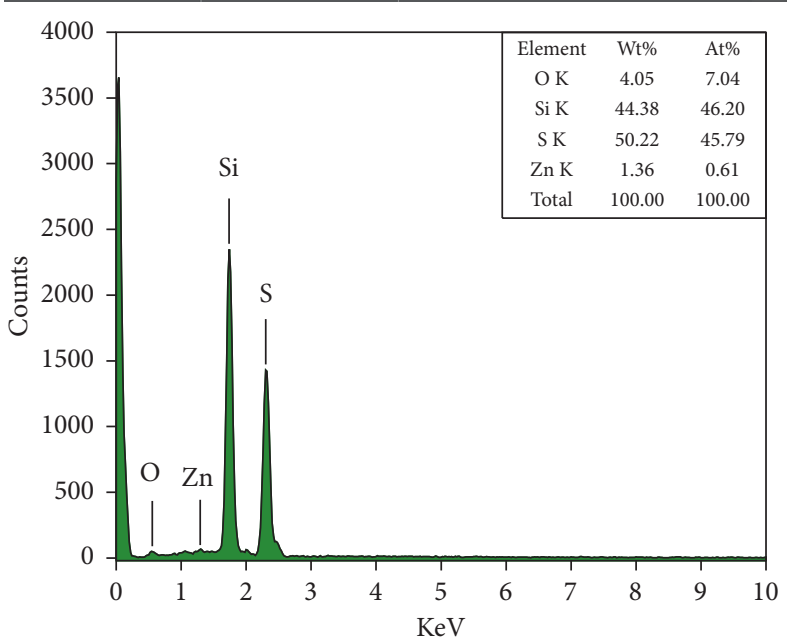

(c)

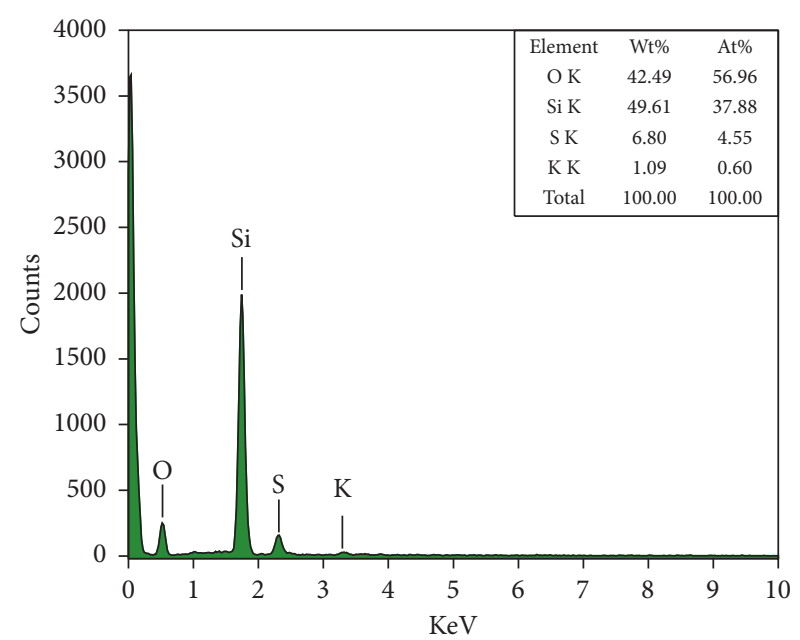

(d)

FIgURE 9: Continued. 

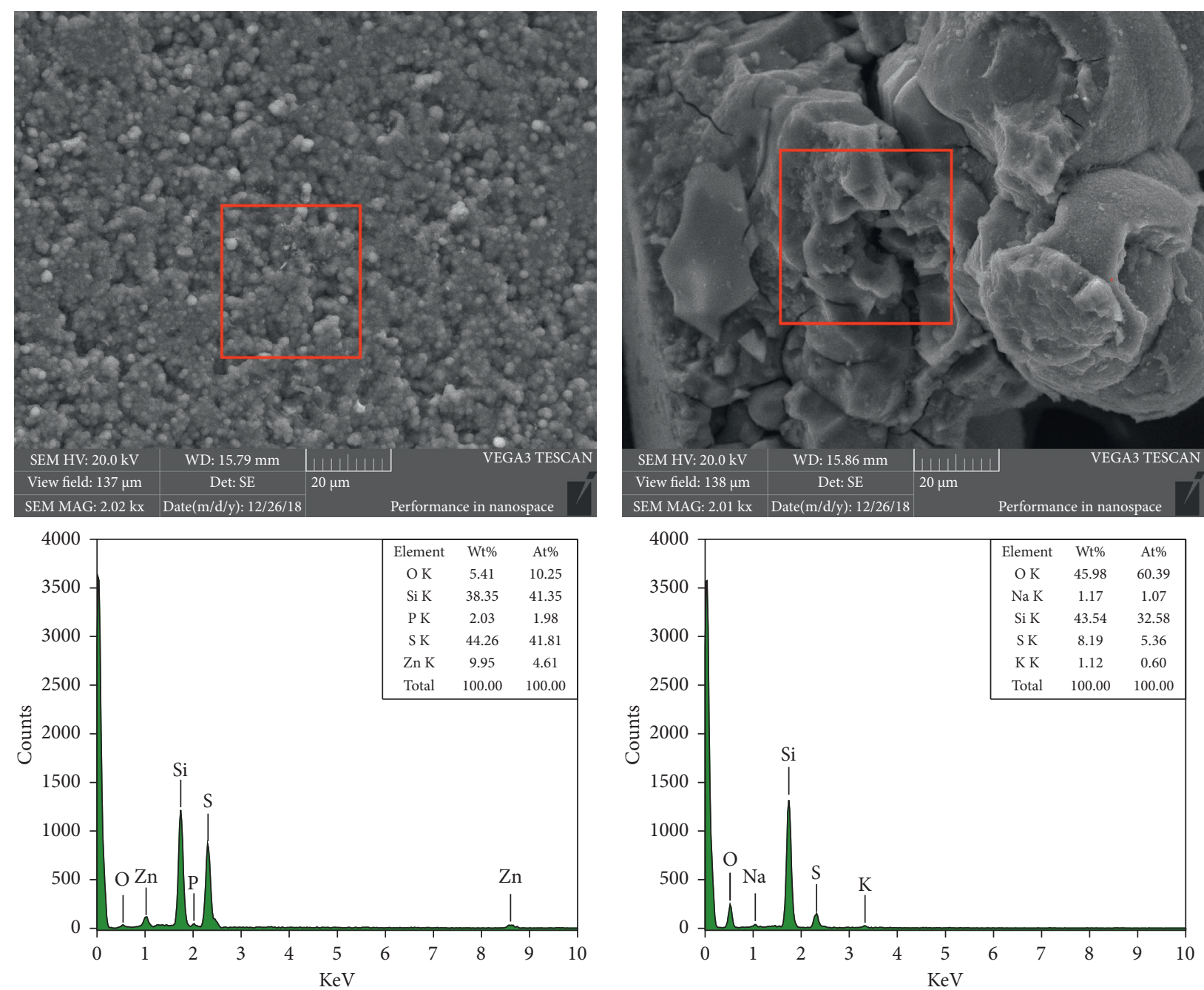

(e)

(f)

FIgure 9: Continued. 

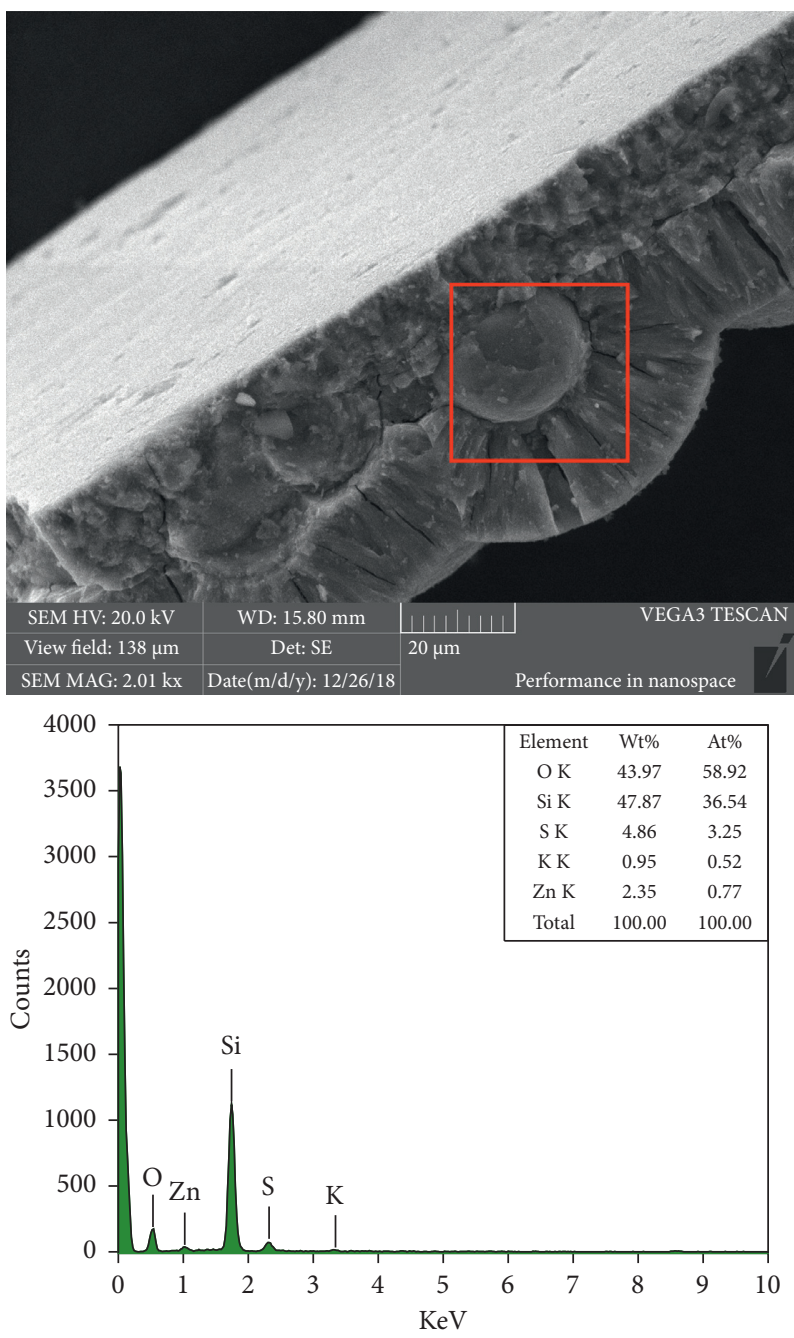

(g)

Figure 9: SEM-EDS analysis of volatile condensates at $1,200^{\circ} \mathrm{C}$.

$$
\begin{aligned}
& \mathrm{FeS}_{2}+\mathrm{C}=\mathrm{Fe}+\mathrm{CS}_{2(\mathrm{~g})}, \\
& 3 \mathrm{C}+\mathrm{SiO}_{2}=\mathrm{SiC}+2 \mathrm{CO}_{(\mathrm{g})}, \\
& 2 \mathrm{C}+\mathrm{SiO}_{2}=\mathrm{Si}_{(\mathrm{g})}+2 \mathrm{CO}_{(\mathrm{g})}, \\
& \mathrm{C}_{\mathrm{n}} \mathrm{H}_{\mathrm{m}} \longrightarrow \mathrm{nC}+\frac{1}{2} \mathrm{mH}_{2(\mathrm{~g})}, \\
& \mathrm{CaCO}_{3}=\mathrm{CaO}+\mathrm{CO}_{2(\mathrm{~g})}, \\
& \mathrm{CaMg}\left(\mathrm{CO}_{3}\right)_{2}=\mathrm{CaO}+\mathrm{MgO}+2 \mathrm{CO}_{2(\mathrm{~g})}, \\
& \mathrm{CaO}+\mathrm{CO}_{2(\mathrm{~g})} \stackrel{\mathrm{H}_{2} \mathrm{O}(\mathrm{g})}{\longrightarrow} \mathrm{CaCO}_{3}, \\
& \mathrm{Fe}_{2} \mathrm{O}_{3}+3 \mathrm{H}_{2(\mathrm{~g})}=2 \mathrm{Fe}+3 \mathrm{H}_{2} \mathrm{O}_{(\mathrm{g})} .
\end{aligned}
$$

The main reaction process of the vacuum roasting pretreatment process is as follows:
(1) The Reactions of $\mathrm{FeS}_{2}$. Under vacuum condition, the decomposition reaction of $\mathrm{FeS}_{2}$ could take place at $513^{\circ} \mathrm{C}$, and the temperature of carbothermic reduction reactions is $470^{\circ} \mathrm{C}$ and $731^{\circ} \mathrm{C}$, respectively. Therefore, the carbothermic reduction reactions might take place preferentially in actual reactions. During the roasting experiment, yellow gas was produced at $500 \sim 600^{\circ} \mathrm{C}$, which gradually condenses and eventually becomes sulfur during the cooling process. The decomposition reaction of $\mathrm{FeS}_{2}$ was verified. Therefore, both the decomposition reaction and the carbothermic reduction reaction of $\mathrm{FeS}_{2}$ could take place in the range of experimental temperature.

(2) The Reactions of $\mathrm{SiO}_{2}$. The carbothermal reductions of $\mathrm{SiO}_{2}$ in vacuum roasting pretreatment process were very complicated. Thus, the thermodynamic analysis only listed the reactions with significant products in the experimental process [39]. The first carbothermal reduction reaction (equation (4)) could take place at $927^{\circ} \mathrm{C}$, and this could be 


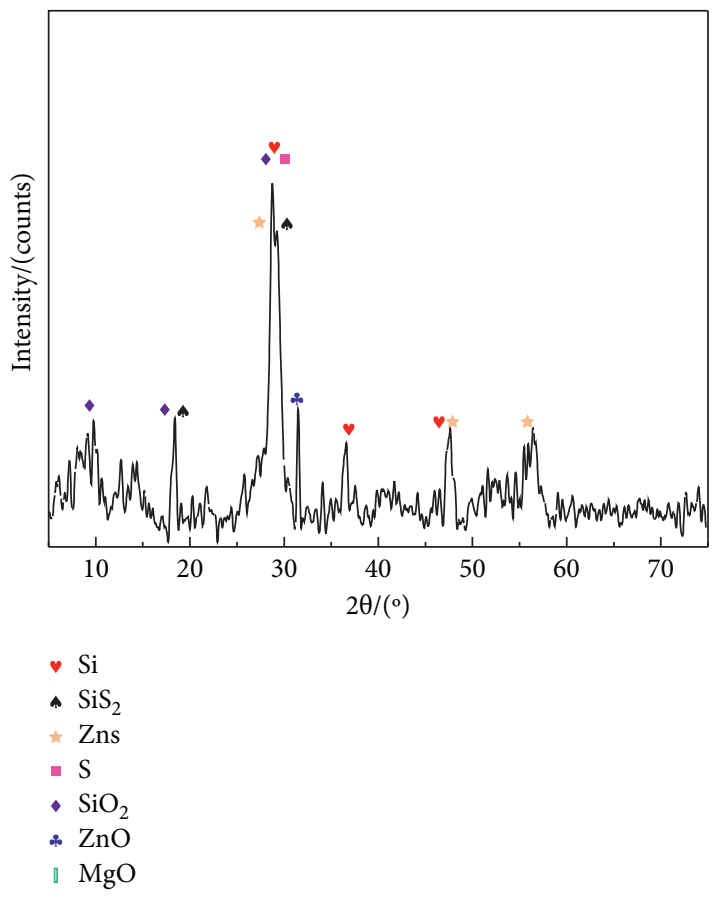

Figure 10: XRD analysis of volatile compounds from carbonaceous gold at $1,200^{\circ} \mathrm{C}$.

TABLe 7: Gold phase analysis of calcine.

\begin{tabular}{lcc}
\hline Phase classification & $\mathrm{W}(\mathrm{Au})\left(\mathrm{g} \cdot \mathrm{t}^{-1}\right)$ & Rate of distribution $(\%)$ \\
\hline Exposed and semiexposed gold & 10.43 & 57.56 \\
Carbonate-locked gold & 3.14 & 17.33 \\
Hematite and limonite-locked gold & 0.89 & 4.91 \\
Sulfides-locked gold & 1.01 & 5.57 \\
Silicate-locked gold & 2.65 & 14.63 \\
Total & 18.12 & 100.00 \\
\hline
\end{tabular}

confirmed with the $\mathrm{SiC}$ that appeared in calcine at $1,200^{\circ} \mathrm{C}$ in the XPS analysis part. The second reaction (equation (5)) could take place at $1155^{\circ} \mathrm{C}$. The silicon in the product was in a gaseous state firstly and then it condensed on the tube wall, which showed how the silicon in the condensate came from. Therefore, the carbothermal reduction of $\mathrm{SiO}_{2}$ could take place in the range of experimental temperature, and the treatment of $\mathrm{SiO}_{2}$ was effective.

(3) The Carbonaceous Matter Reactions. The carbonaceous matter was grouped by elemental carbon and organic carbon in the original sample. In theory, all of the carbothermal reduction reactions (equations (2)-(5)) of elemental carbon could take place, while with the small initial content of elemental carbon, only two lower temperature reactions (equations (2) and (3)) might take place in real experiments. The thermal decomposition and dehydrogenation reactions (equation (6)) might be the main reactions of organic carbon. The thermal decomposition reaction was a seriously mass-weightless process, which might end at about $900-1,000^{\circ} \mathrm{C}$. The dehydrogenation reaction was the second reaction stage of organic carbon, which continuously produced carbon. And this was also the reason for the increase of graphite content in calcine at $1,200^{\circ} \mathrm{C}$. This elemental carbon produced by organic carbon could continue to participate in the reaction of other substances, such as the carbothermal reduction reaction (equations (4) and (5)).

(4) Reactions of Other Substances. Carbonates content decreased first and then increased during the pretreatment process, which was related to the decomposition and formation reactions of carbonates (equations (7)-(9)). The decomposition reaction of dolomite and calcite occurred at $332^{\circ} \mathrm{C}$ and $470^{\circ} \mathrm{C}$, so the carbonates were hard to be detected at $800^{\circ} \mathrm{C}$. After $800^{\circ} \mathrm{C}$, there might be water vapor from the pyrolysis of organic carbon in the system, and the reaction of $\mathrm{CaO}$ with water and $\mathrm{CO}_{2}$ could reproduce calcite. Therefore, carbonates could be detected at $1,200^{\circ} \mathrm{C}$ again. Other substances, such as goethite, kaolinite, mica mineral, and potash feldspar, mainly undergo dehydration reactions before $300^{\circ} \mathrm{C}$. The 


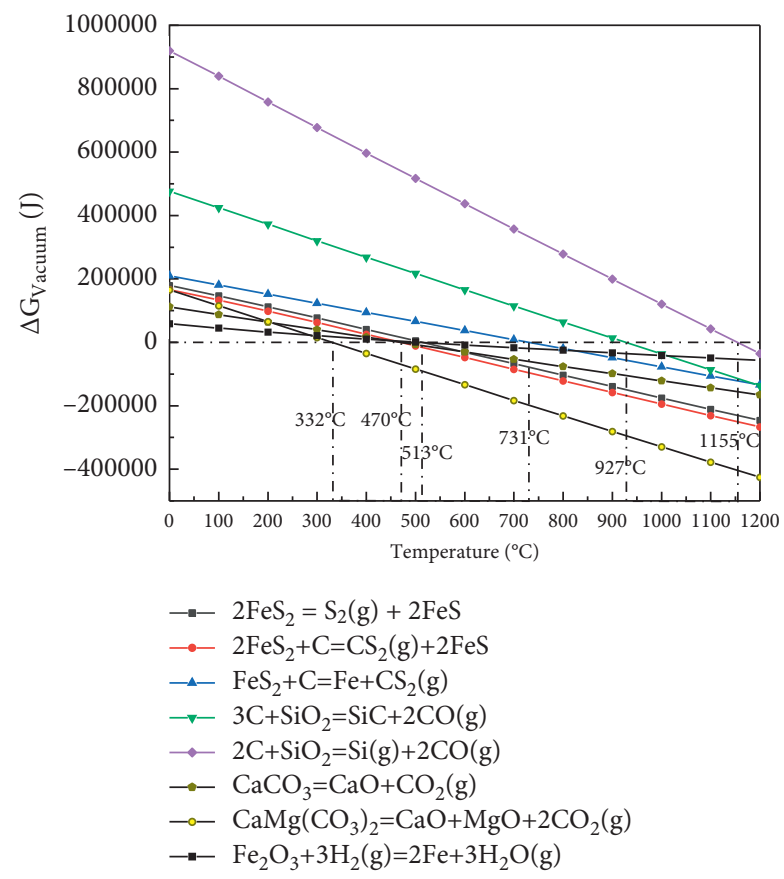

FIGURE 11: The results of thermodynamic analysis of main reactions in vacuum atmosphere.

goethite could be reduced by $\mathrm{H}_{2}$ (equation (10)) which was generated in the thermal decomposition and dehydrogenation reactions of organic carbon at $500^{\circ} \mathrm{C}$ after its dehydration reaction. With the low content, it was difficult to analyze the late reactions of these substances. In addition to the reactions of minerals occurring in the heating region, a variety of products could be seen in the condensation region, which might be products of the reactions of the original substances or secondary products of these reactions. Therefore, these complex reactions in the vacuum roasting pretreatment process were still needed to be further studied.

3.4.2. The Mechanism Diagram of Major Reactions. The main factors affecting gold leaching could be effectively improved by the vacuum roasting pretreatment method. Bellow $800^{\circ} \mathrm{C}$, the main reactions were dehydration reactions of water-bearing materials, decomposition reactions and carbothermic reduction reactions of sulfides ores, and thermal decomposition reactions of organic carbon. Above $800^{\circ} \mathrm{C}$, the main reactions were carbothermic reduction reactions of $\mathrm{SiO}_{2}$, thermal decomposition reactions of organic carbon, and some complex reactions of other prime matters or their secondary reaction. Figure 12 only shows the main reaction process of sulfides ore and carbonaceous matters to make the reaction process clearer.

3.5. Analysis of Leaching Effect. The gold leaching results under different pretreatment temperatures are shown in Figure 13. The results showed that the gold leaching rate gradually increased with the increase of temperature under the vacuum roasting condition; it increased from $2.13 \%$ to $88.37 \%$ after pretreatment at $1,200^{\circ} \mathrm{C}$. Combined with Table 4 and Figure 13, the gold leaching rate was low when the roasting temperature is less than $800^{\circ} \mathrm{C}$, while the organic carbon content was high (Table 4). With the temperature increase after $800^{\circ} \mathrm{C}$, the organic carbon content significantly decreased, whereas the gold leaching rate evidently increased. This finding showed that organic carbon was the main factor affecting the gold leaching rate in the carbonaceous gold concentrates.

It is worth noting that the exposed and semiexposed gold increased to $57.56 \%$ after roasting at $1,200^{\circ} \mathrm{C}$, but the gold leaching rate reached $88.37 \%$ finally. The result suggested that some of the locking gold was also leached. This might be due to the fact that the locking in the raw samples was broken. The locking did not completely abolish finally; this might be due to the new secondary locking produced by some reactions. However, the secondary locking might not be as tight as the original locking after a series of reactions and might leach more easily during the leaching process.

\section{Discussion}

The vacuum roasting pretreatment technology increased the gold recovery by solving the problems of "preg-robbing" and gold-locked. The gold leaching rate was immensely improved with vacuum roasting pretreatment at $1,200^{\circ} \mathrm{C}$; however, there was still $11.63 \%$ of gold being lost; this part of the gold loss was a mystery and needs further study to get the ideal gold leaching rate [40]. That is to say, the fundamental reason why the gold was difficult to be recovered needed to be further studied. It was of great indicative significance to the selection of the pretreatment 


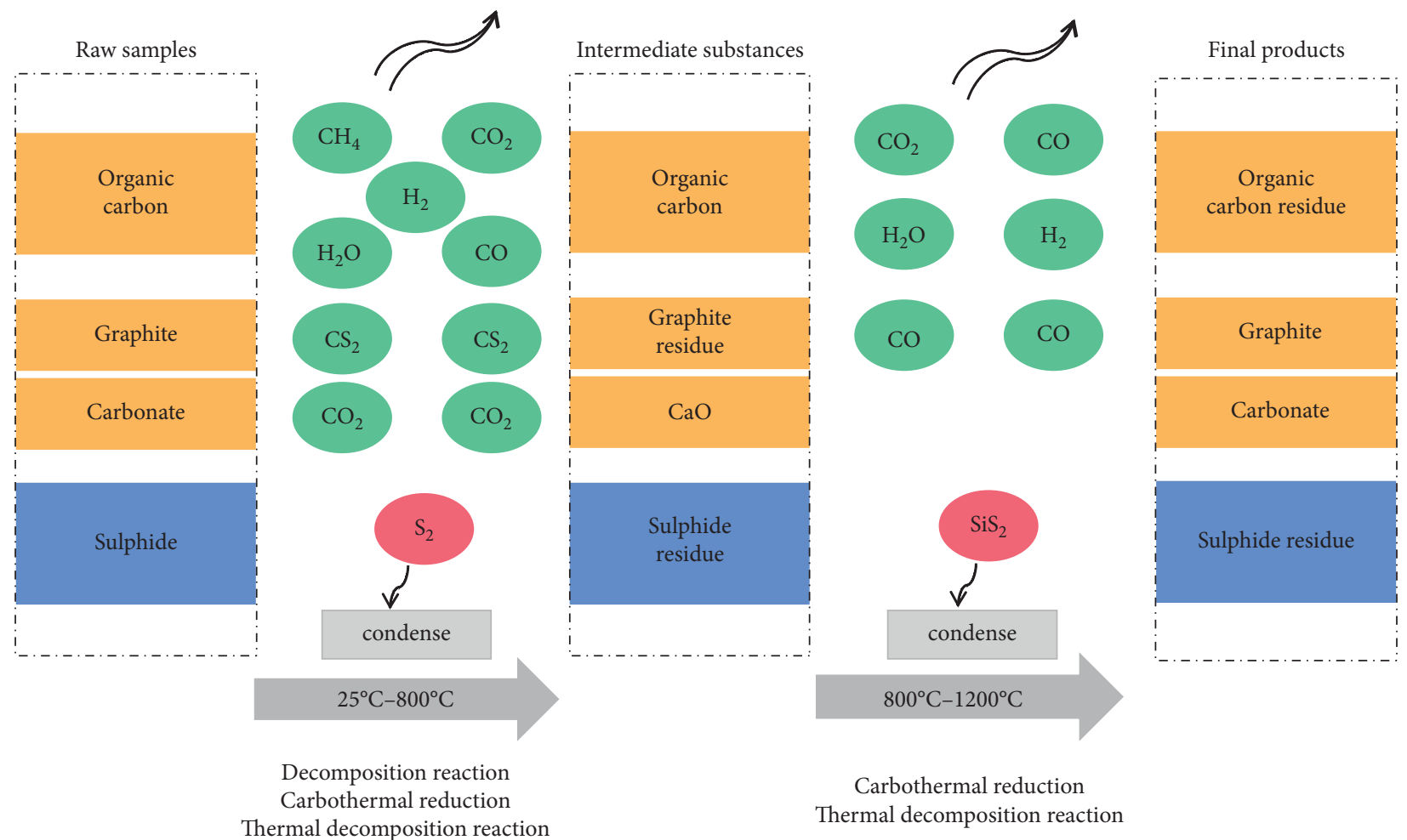

Figure 12: The main reaction process of sulfide ores and carbonaceous matters.

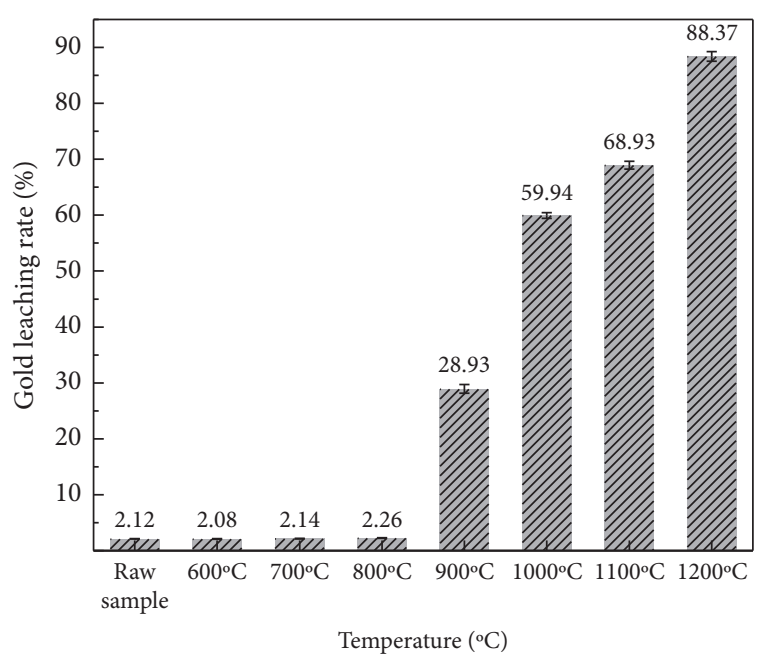

FIgURE 13: Results of cyanidation tests at different temperatures.

process for the same kind of carbonaceous gold ore, and it could also explain why the conventional roasting pretreatment and preferential flotation of carbonaceous matters cannot achieve good results.

It is interesting that a large number of volatile condensates like elemental Si and S were produced during the vacuum roasting pretreatment process. The variation characteristics of condensate at different temperatures and whether they were available or not were worth studying; it was also an important aspect of maximizing the utilization of samples. The recovery of condensation was not easy due to the immaturity of test equipment in the present research. Improving the experimental equipment for more scientific recovery of volatile condensates is necessary for future research.

\section{Conclusions}

A good effect with the gold leaching rate increase from $2.13 \%$ to $88.37 \%$ was obtained with the vacuum degree of $10 \mathrm{~Pa}$ and the temperature of $1,200^{\circ} \mathrm{C}$ for 30 minutes. The removal of sulfur and carbonaceous matters during the vacuum roasting process was $95.83 \%$ and $65.38 \%$, respectively. The content of exposed and semiexposed gold increased from $34.65 \%$ to $57.56 \%$, which was beneficial to the gold leaching.

In the vacuum roasting pretreatment process of carbonaceous gold concentrate ores, the effect of temperature was obvious, and the increase of temperature was conducive to the carbothermal reduction reactions and the thermal decomposition of organic carbon. The pretreatment effects increased after $800^{\circ} \mathrm{C}$, at which the thermal decomposition of organic carbon was gradually completed. Some of the carbonaceous matters contained in the carbonaceous gold ores became the reductant to participate in the reaction, which not only realized the recovery of the target minerals but also realized the purpose of waste utilization. The recovery of gold could be effectively improved by removing the carbonaceous matters and reducing the gold locking of sulfide ores. With the $\mathrm{S}$ element transformed into $\mathrm{S}_{2}$ instead of $\mathrm{SO}_{2}$, the cost of waste gas treatment could be reduced. This research provides a new idea for the comprehensive utilization of carbonaceous materials and the development of a roasting pretreatment method for carbonaceous gold ore. 


\section{Data Availability}

The data used to support the findings of this study are included within the article.

\section{Conflicts of Interest}

The authors declare that they have no conflicts of interest.

\section{Acknowledgments}

This work was supported by the National Natural Science Foundation of China (51774227 and 52074068).

\section{References}

[1] M. Pourdasht, "Study on the surface features of Preg-Robbing carbonaceous matter during oxidation treatment," Electronic Thesis and Dissertation Repository, The University of Western Ontario, London, Ontario, Article ID 5366, 2018.

[2] H.-y. Yang, Q. Liu, X.-l. Song, and J.-k. Dong, "Research status of carbonaceous matter in carbonaceous gold ores and biooxidation pretreatment," Transactions of Nonferrous Metals Society of China, vol. 23, no. 11, pp. 3405-3411, 2013.

[3] T. Pan, S. U. N. Feng-yue, and J. Shao, "Comparative analysis OF carliin-type gold ores between americ and western China," Geology and Resources, vol. 12, no. 4, pp. 248-252, 2003.

[4] Z. J. Zhang, Q. Q. Wang, and S. J. Dai, “The development of pretreatment technology of carbonaceous gold ore," Conservation and Utilization of Mineral Resources, vol. 40, no. 5, pp. 99-104, 2017.

[5] T. Bai, H.-y. Lei, Z. Lei, and S. Li, "Dearsenification of gold concentrates via microwave roasting," Canadian Metallurgical Quarterly, vol. 59, no. 1, pp. 60-66, 2020.

[6] A. D. Bas, F. Larachi, and P. Laflamme, "The effect of pyrite particle size on the electrochemical dissolution of gold during cyanidation," Hydrometallurgy, vol. 175, pp. 367-375, 2018.

[7] J. Jin, Y. Han, H. Li et al., "Mineral phase and structure changes during roasting of fine-grained carbonaceous gold ores and their effects on Au leaching efficiency," Chinese Journal of Chemical Engineering, vol. 27, no. 05, pp. 1184-1190, 2019.

[8] G. Ofori-Sarpong, R. K. Amankwah, and K. Osseo-Asare, "Reduction of preg-robbing by biomodified carbonaceous matter - a proposed mechanism," Minerals Engineering, vol. 42, pp. 29-35, 2013.

[9] R. Ahtiainen, M. Lundström, and J. Liipo, "Preg-robbing verification and prevention in gold chloride-bromide leaching," Minerals Engineering, vol. 128, pp. 153-159, 2018.

[10] B. Nanthakumar, C. A. Pickles, and S. Kelebek, "Microwave pretreatment of a double refractory gold ore," Minerals Engineering, vol. 20, no. 11, pp. 1109-1119, 2007.

[11] K. E. HAQUE, "Refractoriness of certain gold ores to cyanidation: probable causes and possible solutions," Mineral Processing and Extractive Metallurgy Review, vol. 2, pp. 331-352, 1987.

[12] P. C. Holloway and T. H. Etsell, "Transformational roasting in the treatment of metallurgical wastes," Mineral Processing and Extractive Metallurgy, vol. 117, no. 1, 2008.

[13] B. Yang, D. Huang, D. Liu, G. Zha, W. Jiang, and X. Kong, "Research and industrial application of a vacuum separation technique for recovering valuable metals from copper dross," Separation and Purification Technology, vol. 236, Article ID 116309, 2020.
[14] L. Z. Xiong, Y. H. Xiang, X. W. Wu, Z. Q. He, and Z. L. Yin, "Preparation of high purity zinc from zinc oxide ore by vacuum carbothermic reduction," Vacuum, vol. 146, pp. 200-205, 2017.

[15] N. Xiong, Y. Tian, B. Yang, B.-q. Xu, T. Dai, and Y.-n. Dai, "Results of recent investigations of magnesia carbothermal reduction in vacuum," Vacuum, vol. 160, pp. 213-225, 2019.

[16] Z. Yin, W. Lu, and H. Xiao, "Arsenic removal from coppersilver ore by roasting in vacuum," Vacuum, vol. 101, pp. 350-353, 2014.

[17] V.A. Luganov, X. Zhang, and H. Li, "Treatment process of gold ore containing arsenic," Metallic Ore Dressing Abroad, vol. 41, no. 11, pp. 14-18, 2004.

[18] E. Wu, J. Li, and P. Huang, "Synthesis and electrical properties of $\mathrm{C} / \mathrm{TiO} 2-\mathrm{x}$ powers by carbothermal reduction," Chinese Journal of Rare Metals, vol. 44, no. 10, 2020, http://kns.cnki. $\mathrm{net} / \mathrm{kcms} /$ detail/11.2111.TF.20190528.1657.004.html.

[19] H. Wu, Y. Feng, H. Li, H. Wang, and J. Ju, "Co-recovery of manganese from pyrolusite and gold from carbonaceous gold ore using fluidized roasting coupling technology," Chemical Engineering and Processing - Process Intensification, vol. 147, Article ID 107742, 2020.

[20] Y. Liu, Y. Du, and X. Zhu, "Mechanism of the India by carbothermic reduction reaction from India ore in vacuum," Advanced Materials Research, vol. 1096, pp. 256-261, 2015.

[21] L. Qi, T. Qu, and D. Liu, "Characteristics of vacuum carbothermal reduction of Nickel Laterite," Journal of Vacuum Science and technology, Article ID 3211, 2012.

[22] Y. Song, X. Zhang, and N. Yin, "A pretreatment method for carbonaceous gold concentrate and its preparation method and gold extraction method," pp. 2105-14, 2021, Shaanxi Province: CN110484719B.

[23] G. Greczynski and L. Hultman, "X-ray photoelectron spectroscopy: towards reliable binding energy Referencing," Progress in Materials Science, vol. 107, Article ID 100591, 2020.

[24] A. T. Ubando, W.-H. Chen, and H. C. Ong, "Iron oxide reduction by graphite and torrefied biomass analyzed by TGFTIR for mitigating CO2 emissions," Energy, vol. 180, pp. 968-977, 2019.

[25] M. C. Biesinger, B. P. Payne, A. P. Grosvenor, L. W. M. Lau, A. R. Gerson, and R. S. C. Smart, "Resolving surface chemical states in XPS analysis of first row transition metals, oxides and hydroxides: Cr, Mn, Fe, Co and Ni," Applied Surface Science, vol. 257, no. 7, pp. 2717-2730, 2011.

[26] L. I. U. Rong-xiang, J. LI, and S. U. Wen-rou, "FTIR and XPS analysis comparing the activation mechanism of $\mathrm{Ca} 2+$ and Fe3+ on quartz," Spectroscopy and Spectral Analysis, vol. 40, no. 06, pp. 1876-1882, 2020.

[27] H. Nohira, W. Tsai, W. Besling et al., "Characterization of ALCVD-Al2O3 and $\mathrm{ZrO} 2$ layer using X-ray photoelectron spectroscopy," Journal of Non-crystalline Solids, vol. 303, no. 1, pp. 83-87, 2002.

[28] S. Tengeler, B. Kaiser, G. Ferro, D. Chaussende, and W. Jaegermann, "The (001) 3C SiC surface termination and band structure after common wet chemical etching procedures, stated by XPS, LEED, and HREELS," Applied Surface Science, vol. 427, pp. 480-485, 2018.

[29] S. Cichon, P. Machác, B. Bardaa, and M. Kudrnováb, "Si ohmic contacts on N-type SiC studied by XPS," Microelectronic Engineering, vol. 106, pp. 132-138, 2013.

[30] G. Greczynski and L. Hultman, "C 1s peak of adventitious carbon aligns to the vacuum level: dire consequences for material's bonding assignment by photoelectron spectroscopy," ChemPhysChem, vol. 18, no. 12, pp. 1507-1512, 2017. 
[31] J. A. Donadelli, A. Cánneva, G. Erra, and A. Calvo, "XPS direct analysis on shale rocks: correlation with kerogen type and maturity," Fuel, vol. 257, Article ID 116004, 2019.

[32] S. Tengeler, B. Kaiser, D. Chaussende, and W. Jaegermann, "(001) 3C SiC/Ni contact interface: in situ XPS observation of annealing induced Ni2Si formation and the resulting barrier height changes," Applied Surface Science, vol. 400, pp. 6-13, 2017.

[33] R. Huang, P. Liu, X. Qian, and J. Zhang, "Comprehensive utilization of Panzhihua ilmenite concentrate by vacuum carbothermic reduction," Vacuum, vol. 134, pp. 20-24, 2016.

[34] L. qi, T. Qu, D. Liu, Y. Tian, B. Yang, and Y. Dai, "Behavior of silicon in vacuum carbothermic reduction of saprolite nickel laterite," Journal of Vacuum Science and Technology, vol. 32, no. 05, pp. 430-436, 2012.

[35] S. Ma, C. Sun, X. Zhang, J. Kou, and M. Su, "Kinetics of thermal decomposition reaction of pyrite roasted by microwave," China Mining Magazine, vol. 27, no. 05, pp. 138-142, 2018.

[36] L. Qi, D. Liu, and T. Qu, "Volatile behavior of silicon by carbothermic reduction in vacuum," Journal of Central South University, vol. 43, no. 8, pp. 2900-2908, 2012.

[37] S. Ahmed, A. Aitani, F. Rahman, A. Al-Dawood, and F. AlMuhaish, "Decomposition of hydrocarbons to hydrogen and carbon," Applied Catalysis A: General, vol. 359, no. 1-2, pp. 1-24, 2009.

[38] H. Yang, Z. Ma, Y. Zhang, and Y. Li, "Characteristics and kinetic analysis of humic acid pyrolysis of weathered coal," Coal conversion, vol. 37, no. 04, pp. 74-80, 2014.

[39] R. Nagahata, Y. Mori, Y. Saito et al., "Efficient carbothermal reduction of diatomaceous earth to silicon using microwave heating," Materials Chemistry and Physics, vol. 257, 2020, Article ID 123744, https://doi.org/10.1016/j.matchemphys. 2020.123744.

[40] S. S. Dimov and B. R. Hart, "Applications of microbeam analytical techniques in gold deportment studies and characterization of losses during the gold recovery process," Surface and Interface Analysis, vol. 49, no. 13, pp. 1404-1415, 2017. 